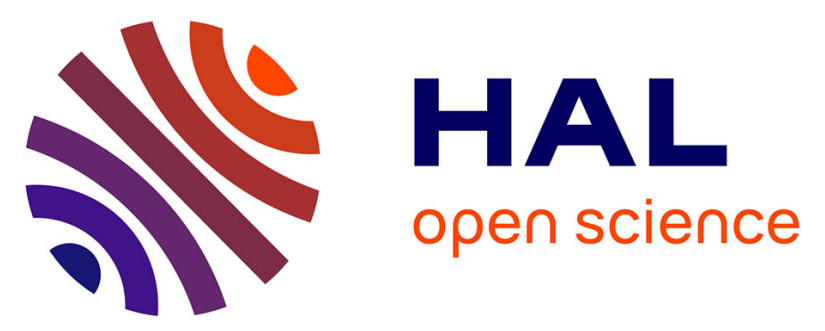

\title{
Expanding the Toolbox of Octahedral Molybdenum Clusters and Nanocomposites Made Thereof: Evidence of Two-Photon Absorption Induced NIR Emission and Singlet Oxygen Production
}

\author{
Soumaya Khlifi, Gregory Taupier, Maria Amela-Cortes, Noée Dumait, \\ Stéphane Freslon, Stéphane Cordier, Yann Molard
}

\section{To cite this version:}

Soumaya Khlifi, Gregory Taupier, Maria Amela-Cortes, Noée Dumait, Stéphane Freslon, et al.. Expanding the Toolbox of Octahedral Molybdenum Clusters and Nanocomposites Made Thereof: Evidence of Two-Photon Absorption Induced NIR Emission and Singlet Oxygen Production. Inorganic Chemistry, 2021, 60 (8), pp.5446-5451. 10.1021/acs.inorgchem.1c00517 . hal-03194364

\author{
HAL Id: hal-03194364 \\ https://hal.science/hal-03194364
}

Submitted on 23 Apr 2021

HAL is a multi-disciplinary open access archive for the deposit and dissemination of scientific research documents, whether they are published or not. The documents may come from teaching and research institutions in France or abroad, or from public or private research centers.
L'archive ouverte pluridisciplinaire HAL, est destinée au dépôt et à la diffusion de documents scientifiques de niveau recherche, publiés ou non, émanant des établissements d'enseignement et de recherche français ou étrangers, des laboratoires publics ou privés. 


\title{
Expanding the Toolbox of Octahedral
}

\author{
Molybdenum Clusters and Nanocomposite Made
}

Thereof: Evidence of Two-Photon Absorption

induced -NIR Emission and -Singlet Oxygen

\section{Production.}

Soumaya Khlifi, ${ }^{\dagger}$ Gregory Taupier, ${ }^{\dagger}$ Maria Amela-Cortes,${ }^{\dagger}$ Noée Dumait,$^{\dagger}$ Stéphane Freslon, ${ }^{\dagger}$ Stéphane Cordier, ${ }^{\dagger}$ Yann Molard. ${ }^{\dagger}, *$

†Université de Rennes, CNRS, INSA, ISCR - UMR 6226, ScanMAT - UMS 2001, F-35000

Rennes, France.

KEYWORDS. Metal cluster, luminescence, hybrid materials, two-photon absorption.

ABSTRACT. Octahedral Molybdenum clusters bright NIR phosphorescence is known since the 80 's. However, their behavior toward NIR excitation has never been investigated. Here we report their abilities to emit NIR light and produce singlet oxygen upon two-photon absorption. This behavior is observed in solution, in the solid-state as well as when clusters are embedded homogeneously in a poly(dimethylsiloxane) matrix. Such discoveries open new perspectives in several fields like optoelectronic, photodynamic therapy or bioimaging. 
Octahedral transition metal cluster based compounds ${ }^{1}$ of general formula $\mathrm{A}_{\mathrm{x}} \mathrm{M}_{6} \mathrm{X}_{8}{ }_{8} \mathrm{~L}_{6}^{\mathrm{a}}(\mathrm{A}$ : monovalent cation, $\mathrm{x}=2$ and $\mathrm{M}=\mathrm{Mo}$ or $\mathrm{W} ; \mathrm{x}=4$ and $\mathrm{M}=\mathrm{Re}, \mathrm{X}^{\mathrm{i}}$ : halogen or chalcogen inner ligand, $\mathrm{L}^{\mathrm{a}}$ : anionic apical ligand) have attracted the attention of many research groups this last decade for their abilities to emit in the red-NIR and produce singlet oxygen upon either UVVis or X-ray irradiation. ${ }^{2-6}$ Many studies have described their potential in cancer treatment, ${ }^{7-8}$ bioimaging, ${ }^{9}$ optoelectronic, ${ }^{10-13}$ lighting, ${ }^{14-15}$ solar concentrator, ${ }^{16-17}$ anticouterfeiting, ${ }^{18}$ oxygen sensors ${ }^{19-22}$ or photocatalysis. $^{23}$ Herein, we demonstrate the ability of $\mathrm{A}_{2} \mathrm{Mo}_{6} \mathrm{I}_{8}{ }_{8}\left(\mathrm{OCOC}_{2} \mathrm{~F}_{5}\right)_{6}^{\mathrm{a}}(\mathrm{A}=$ alkali or organic cation $)$ to emit red-NIR light and generate singlet oxygen upon NIR excitation by a two-photon absorption (TPA) process. This feature is observed in solution, in the solid-state as well as when $\mathrm{A}_{2} \mathrm{Mo}_{6} \mathrm{I}_{8}{ }_{8}\left(\mathrm{OCOC}_{2} \mathrm{~F}_{5}\right)_{6}^{\mathrm{a}}$ is homogeneously embedded in an optically clear, inert and biocompatible host matrix: poly(dimethylsiloxane) (PDMS). Known for about 90 years, ${ }^{24}$ TPA-induced luminescence is still an active area of research in the field of nanomaterials, because of its potential in applications like: threedimensional optical data storage, ${ }^{25}$ multiphoton emission spectroscopy and microscopy ${ }^{26}$ or photodynamic therapy (PDT). ${ }^{27-28}$ In this last case, materials endowed with TPA-induced phosphorescence are particularly appealing. NIR excitation minimizes tissue autofluorescence and provides a deeper penetration in biological tissues compared to visible light. Moreover, as the triplet excited state reached by TPA is able to produce singlet oxygen by energy transfer, materials capable of such feature are prime candidates for non-invasive therapy. Hence, new materials have been developed using coordination complexes or organic compounds, ${ }^{29}$ quantum dots, ${ }^{30}$ rare earth ${ }^{31-33}$ and more recently carbon dots or silicon dots coupled to platinum group metals,$^{34}$ or tetranuclear cubane-like $\mathrm{Cu}(\mathrm{I})$ compounds. ${ }^{35}$ Being aware of the cadmium containing quantum dots toxicity, the high price of platinum group metals and the geopolitical uncertainty of rare earth availability, ${ }^{36}$ Mo based clusters represent a viable alternative in the field of red-NIR phosphorescent emitters. Moreover, although third-order non-linear optical 
properties of cubane-like or triangular $^{38-39}$ Mo clusters have been investigated for photonic applications, TPA induced emission of octahedral Mo clusters has never been investigated so far.

Hybrid PDMS was obtained by a hydrosilylation reaction between monomers containing allyl functions and anionic clusters whose charge is counterbalanced by organic cations bearing silane end groups ( $\mathrm{Cat}_{2} \mathrm{Mo}_{6}$, Figure 1a, see ESI for experimental procedure) using a Karstedt platinum catalyst. This approach is very efficient to integrate homogeneously octahedral clusters into polymers ${ }^{19}$ and allows high doping rate. Moreover, unlike a simple mixing of unreactive cluster salt with PDMS precursors, ${ }^{40}$ such strategy leads to strong interactions between the host matrix and the integrated dye. As a result, it prevents any unwanted phase segregation or leaching, of particular relevance when dealing with biological in vivo applications. At this stage we wish to emphasize that the photophysical properties of doped PDMS samples were analyzed twice: firstly, few days after their synthesis and secondly, after 48 months of ageing. As similar results were obtained (vide infra), it demonstrates the relevance and the robustness of the chosen integration strategy. Hence, samples made from 1, 5 and 10 wt $\%$ of Cat ${ }_{2} \mathrm{Mo}_{6}$ namely PDMS1, PDMS5 and PDMS10 respectively, were synthesized. A reference sample (PDMS) without cluster was also synthesized to observe the influence of cluster content on the thermal decomposition and glass transition temperatures. The success of the polymerization was assessed by IR spectroscopy looking at the lack of precursors vibration bands corresponding to Si-H elongation around $2150-2200 \mathrm{~cm}^{-1}$ and vinyl C-H elongation after $3000 \mathrm{~cm}^{-1}$ (see ESI, Figure S1 for IR spectra). The homogeneity of cluster compounds distribution within the PDMS matrix was confirmed by SEM and EDS analysis (see ESI, Figure S2). Thermal gravimetric analysis (TGA, see ESI Figure S3) were realized by heating samples up to $700^{\circ} \mathrm{C}$ in air atmosphere at $10^{\circ} \mathrm{C} \mathrm{min}^{-1}$. Due to the large degree of crosslinking, PDMS samples show a high thermal stability. 

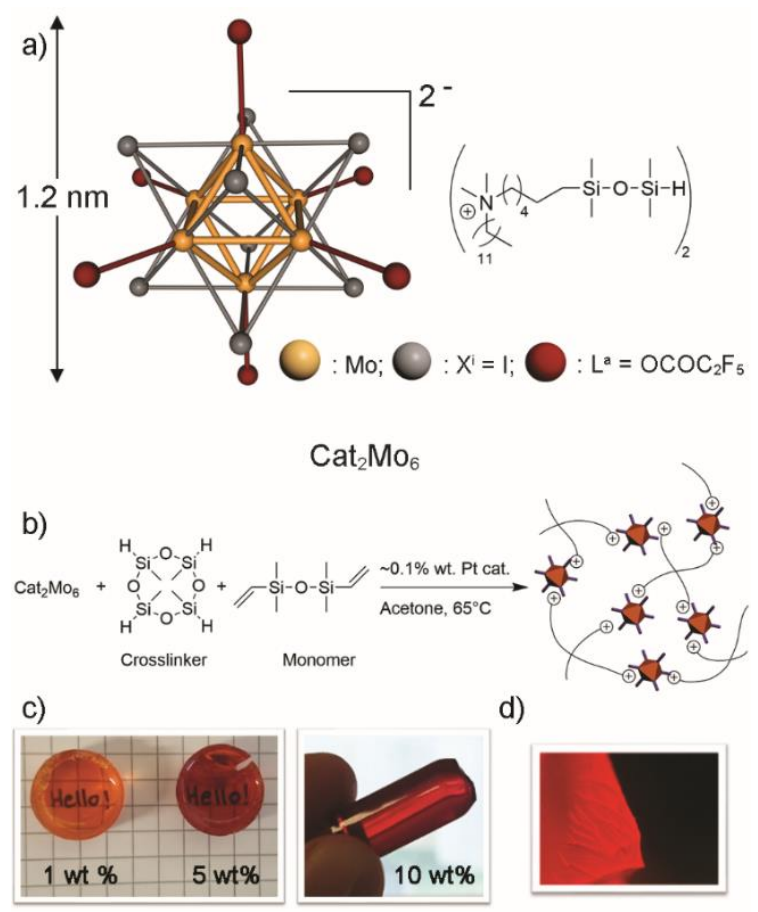

Figure 1. a) Representation of $\mathrm{Cat}_{2} \mathrm{Mo}_{6}$ containing the $\left[\mathrm{Mo}_{6} \mathrm{I}_{8}{ }_{8}\left(\mathrm{OCOC}_{2} \mathrm{~F}_{5}\right)^{\mathrm{a}}{ }_{6}\right]^{2-}$ anionic cluster unit $\left(\mathrm{Mo}_{6}\right)$ and two polymerizable counter-cation (Cat); b) reaction scheme of hybrid PDMS synthesis; c) pictures under ambient light of PDMS1, PDMS5 and PDMS10; d) picture of a piece of PDMS10 taken under microscope and UV-A irradiation.

The thermal decomposition temperature $\left(\mathrm{T}_{\mathrm{d}}\right.$, Table 1) recorded for neat PDMS is at $510^{\circ} \mathrm{C}$ and only one and broad decomposition step is observed. For doped PDMS, the thermal decomposition occurs in three steps starting around $150^{\circ} \mathrm{C}, 280^{\circ} \mathrm{C}$ and $530^{\circ} \mathrm{C}$. These steps correspond respectively to water loss, cluster decomposition (loss of apical ligands $)^{41}$ and main polymer backbone decomposition leading to mineralization. ${ }^{42}$ The cluster decomposition occurring around $280^{\circ} \mathrm{C}$ is only straightforwardly observed for PDMS10 due to the low cluster content in other samples. Glass transition temperatures $\left(\mathrm{T}_{\mathrm{g}}\right)$ were determined by Differential Scanning Calorimetry (DSC, see ESI Figure S4). Introducing $1 \mathrm{wt} \%$ of $\mathrm{Cat}_{2} \mathrm{Mo}_{6}$ in the host matrix has little influence on its $\mathrm{T}_{\mathrm{g}}$ value that passes from $6.6^{\circ} \mathrm{C}$ to $9.3^{\circ} \mathrm{C}$ for PDMS and PDMS1, respectively. However, increasing the cluster content leads to a decrease of the $\mathrm{T}_{\mathrm{g}}$ 
down to $-8.2^{\circ} \mathrm{C}$, attributed to a plastisizing effect already observed for other $\mathrm{Mo}_{6}$ doped copolymers. ${ }^{19,41}$

Emission measurements were realized in acetone solution and on a powdered sample for the $\mathrm{Cs}_{2} \mathrm{Mo}_{6} \mathrm{I}_{8}{ }_{8}\left(\mathrm{OCOC}_{2} \mathrm{~F}_{5}\right)_{6}^{\mathrm{a}}$ precursor used to prepare $\mathrm{Cat}_{2} \mathrm{Mo}_{6}$ and on thin slices of hybrid nanocomposites. First, emission properties due to one photon absorption (1P) were investigated. Excitation spectra recorded for all samples (see ESI Figure S5 for the absorption spectrum of $\mathrm{Cs}_{2} \mathrm{Mo}_{6} \mathrm{I}_{8}{ }_{8}\left(\mathrm{OCOC}_{2} \mathrm{~F}_{5}\right)_{6}^{\mathrm{a}}$ and Figures S6-S10 for emission and excitation spectra) show that the optimal excitation wavelength to observe the $1 \mathrm{P}$ emission ranges from $350 \mathrm{~nm}$ up to $400 \mathrm{~nm}$ in solution and leads to a broad emission band with an emission maximum located between $667 \mathrm{~nm}$ and $688 \mathrm{~nm}$ depending on samples. As expected the non-doped PDMS sample is not luminescent. Absolute quantum yield (AQY) were determined in air and in a saturated $\mathrm{N}_{2}$ atmosphere for solid state samples and on deaerated solutions. It is well known that the phosphorescence of octahedral $\mathrm{Mo}_{6}$ clusters is efficiently quenched by the ground triplet state of $\mathrm{O}_{2}$, thus generating the NIR emissive singlet oxygen. ${ }^{43}$ As, PDMS possesses a high dioxygen permeability, ${ }^{44}$ the emission efficiency of embedded cluster depends strongly on the local $\mathrm{O}_{2}$ concentration and increases strongly upon $\mathrm{N}_{2}$ atmosphere saturation (Table 1). The differences in AQY values found between deaerated solution and doped PDMS in saturated $\mathrm{N}_{2}$ atmosphere are essentially due to residual oxygen trapped within the polymer backbone. The $\mathrm{Cs}_{2} \mathrm{Mo}_{6} \mathrm{I}_{8}{ }_{8}\left(\mathrm{OCOC}_{2} \mathrm{~F}_{5}\right)_{6}^{\mathrm{a}}{ }_{6}$ triplet excited state lifetime varies from few $\mu$ s in air up to $269 \mu \mathrm{s}$ in deaerated solution. Emission decays of hybrid composites were fitted with two components in the $\mu$ s range (see ESI, Figures S11-S22), a usual behavior for solid state clusters, that corresponds to differences in the local environment of the emitters. Similar values are observed for doped PDMS samples either in air or in vacuum.

Two photon emission (2PE) measurements were realized using a Ti-sapphire femtosecond laser chain (Coherent Chameleon ultra II, pulse duration: 100-130 fs; pulse frequency: $5 \mathrm{MHz}$ ) 
at several excitation wavelength ranging from 790 to $900 \mathrm{~nm}$. The $2 \mathrm{PE}$ was recorded perpendicularly to the beam using an optical fiber connected to a CCD detector (see ESI, Figure S23). Emission spectra observed by one or two photon absorption are very similar as presented in Figure 2c (see ESI Figure S24 for all spectra) with emission maxima located nearly at the same position, except for powdered $\mathrm{Cs}_{2} \mathrm{Mo}_{6}{ }_{8}{ }^{\mathrm{i}}\left(\mathrm{OCOC}_{2} \mathrm{~F}_{5}\right)^{\mathrm{a}}{ }_{6}$ for which a local temperature increase is suspected under the laser beam.

Table 1. Thermal and photophysical data of $\mathrm{Cs}_{2} \mathrm{Mo}_{6} \mathrm{I}_{8}{ }_{8}\left(\mathrm{OCOC}_{2} \mathrm{~F}_{5}\right)^{\mathrm{a}}{ }_{6}$ and doped PDMS samples.

\begin{tabular}{|c|c|c|c|c|c|c|c|c|}
\hline & \multirow[t]{2}{*}{$\begin{array}{l}T_{g} \\
\left({ }^{\circ} \mathrm{C}\right)\end{array}$} & \multirow[t]{2}{*}{$\begin{array}{l}T_{d} \\
\left({ }^{\circ} \mathrm{C}\right)\end{array}$} & \multicolumn{2}{|c|}{$\lambda_{\max }(\mathrm{nm})$} & \multicolumn{2}{|c|}{$\begin{array}{l}\text { Kinetic parameters } \\
\tau(\mu \mathrm{s}) / \text { weight }(\%)\end{array}$} & \multicolumn{2}{|c|}{$\Phi(\%)$} \\
\hline & & & $1 \mathrm{P}$ & $2 \mathrm{P}$ & In air & deaerated $^{\mathrm{a}}$ & air & $\mathrm{N}_{2}{ }^{\text {sat }}$ \\
\hline $\begin{array}{l}\mathrm{Cs}_{2} \mathrm{Mo}_{6} \mathrm{I}_{8}{ }_{8}\left(\mathrm{OCOC}_{2} \mathrm{~F}_{5}\right)^{\mathrm{a}}{ }_{6} \\
\text { solution }\end{array}$ & - & - & 670 & 669 & $2^{b}$ & $269^{b}$ & 1 & 56 \\
\hline $\begin{array}{l}\mathrm{Cs}_{2} \mathrm{Mo}_{6} \mathrm{I}_{8}{ }_{8}\left(\mathrm{OCOC}_{2} \mathrm{~F}_{5}\right)^{\mathrm{a}}{ }_{6} \\
\text { powder }\end{array}$ & - & - & 667 & 681 & $\begin{array}{l}5(0.28) \\
50(0.72)\end{array}$ & - & 35 & - \\
\hline PDMS1 & 9.3 & 525 & 685 & 689 & $\begin{array}{l}2.8 \\
(0.81) \\
6.6 \\
(0.19)\end{array}$ & $\begin{array}{l}84(0.39) \\
190(0.61)\end{array}$ & 1 & $24^{\mathrm{c}}$ \\
\hline PDMS5 & -6.3 & 530 & 679 & 679 & $\begin{array}{l}3.5 \\
(0.81) \\
7.7 \\
(0.19)\end{array}$ & $\begin{array}{l}90(0.31) \\
203(0.69)\end{array}$ & 2 & $40^{c}$ \\
\hline PDMS10 & -8.2 & 530 & 688 & 688 & $\begin{array}{l}3.8 \\
(0.87) \\
8.5 \\
(0.13)\end{array}$ & $\begin{array}{l}82(0.18) \\
206(0.82)\end{array}$ & 1 & $50^{c}$ \\
\hline
\end{tabular}

${ }^{\text {a}}$ removal of oxygen is realized by bubbling Ar during $30 \mathrm{~min}$ for solutions, while measurements on PDMS hybrids are realized under dynamic vacuum after $3 \mathrm{~h}$ of pumping ( $\mathrm{P}$ $\approx 1.10^{-6}$ mbar); ${ }^{b}$ from ref ${ }^{15}$; ${ }^{\mathrm{c}}$ saturation is realized by blowing $\mathrm{N}_{2}$ at 0.06 bar during $15 \mathrm{~min}$ in an integrating sphere. Error on AQY values $\pm 10 \%$.

The Red-NIR cluster 2PE under NIR infrared excitation was confirmed by the quadratic dependence of the emission intensities with the excitation laser power, in solution (Figure 2a) 
and in the solid state (ESI, Figure S25) for $\mathrm{Cs}_{2} \mathrm{Mo}_{6} \mathrm{I}_{8}{ }_{8}\left(\mathrm{OCOC}_{2} \mathrm{~F}_{5}\right)^{\mathrm{a}}$, and for PDMS10 (Figure 2b). In this last case, we observed a saturation phenomenon that further leads to the nanocomposite degradation at higher excitation power. In order to avoid thermal phenomena responsible for the shift and lowering of the cluster emission signal, the $\mathrm{Cs}_{2} \mathrm{Mo}_{6} \mathrm{I}_{8}{ }_{8}\left(\mathrm{OCOC}_{2} \mathrm{~F}_{5}\right)_{6}{ }_{6}$ two photon absorption cross section was evaluated only in solution (inset, Figure 2c) by using the following equation:

$$
\sigma_{2}=\frac{n c_{r e f} F \phi_{r e f}}{n_{r e f} c F_{r e f} \phi} \sigma_{2 \text { ref }}(1)
$$

Where ref refers to a reference compound (Rhodamine B in our case), ${ }^{45} n$ are the refractive index of solvents, $c$ the concentration, $F$ the integrated intensity of the emission signal recorded in the exact same conditions and $\Phi$ the emission quantum yield from single photon excitation. ${ }^{46}$ Values are expressed in Göppert-Mayer unit $\left(1 \mathrm{GM}=10^{-50} \mathrm{~cm}^{4} \mathrm{~s}\right.$ photon $\left.{ }^{-1}\right)$ and might appear low compared to carefully engineered TPA emitters like conjugated metalloporphyrins,${ }^{47}$ gold nanorods $^{48}$ or $\mathrm{Cd}$ containing quantum dots. ${ }^{49}$ However, we wish to state that $\mathrm{Cs}_{2} \mathrm{Mo}_{6} \mathrm{I}_{8}{ }_{8}\left(\mathrm{OCOC}_{2} \mathrm{~F}_{5}\right)_{6}^{\mathrm{a}}$ has a low dark toxicity ${ }^{7}$ and that the cluster structure has not yet been optimized to improve such parameter. Indeed, octahedral clusters can be easily functionalized with organic ligands, ${ }^{13,23,50}$ and, designing organic synthons able to improve clusters TPA cross section should be the next step of this research field. Moreover, as stated by Y. Zhao et al., ${ }^{51}$ high TPA cross section values in the $780-820 \mathrm{~nm}$ excitation range are required to be efficiently used in 2PE-PDT applications, and this is exactly the wavelength range where are found the highest TPA cross section values for $\mathrm{Cs}_{2} \mathrm{Mo}_{6} \mathrm{I}_{8}{ }^{\mathrm{i}}\left(\mathrm{OCOC}_{2} \mathrm{~F}_{5}\right)_{6}^{\mathrm{a}}$. Figure 2d shows the $1 \mathrm{PE}$ and 2PE spectra recorded for $\mathrm{Cs}_{2} \mathrm{Mo}_{6}{ }_{8}{ }_{8}{ }_{8}\left(\mathrm{OCOC}_{2} \mathrm{~F}_{5}\right)_{6}^{\mathrm{a}}$ and nanocomposites in the $1200-1350 \mathrm{~nm}$ range where $\mathrm{O}_{2}\left({ }^{1} \Delta_{\mathrm{g}}\right)$ emits. The production of singlet oxygen by 1P absorption of Mo clusters is known for long, ${ }^{43}$ and $\mathrm{O}_{2}\left({ }^{1} \Delta_{\mathrm{g}}\right)$ emission could also be detected for samples with low cluster content. A NIR excitation leads also clearly to the production of singlet oxygen (inset figure 2d), demonstrating that hybrid PDMS can potentially act as TPA-induced PDT agent. 

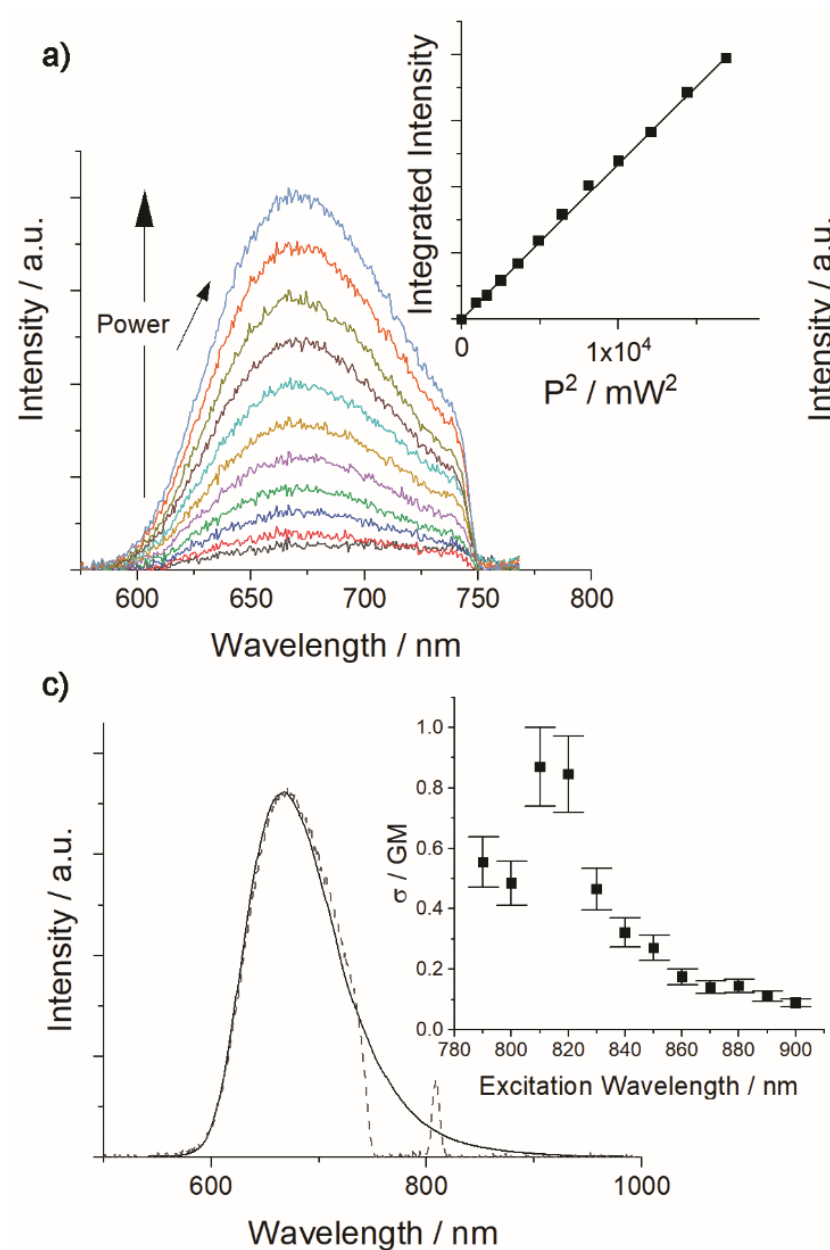

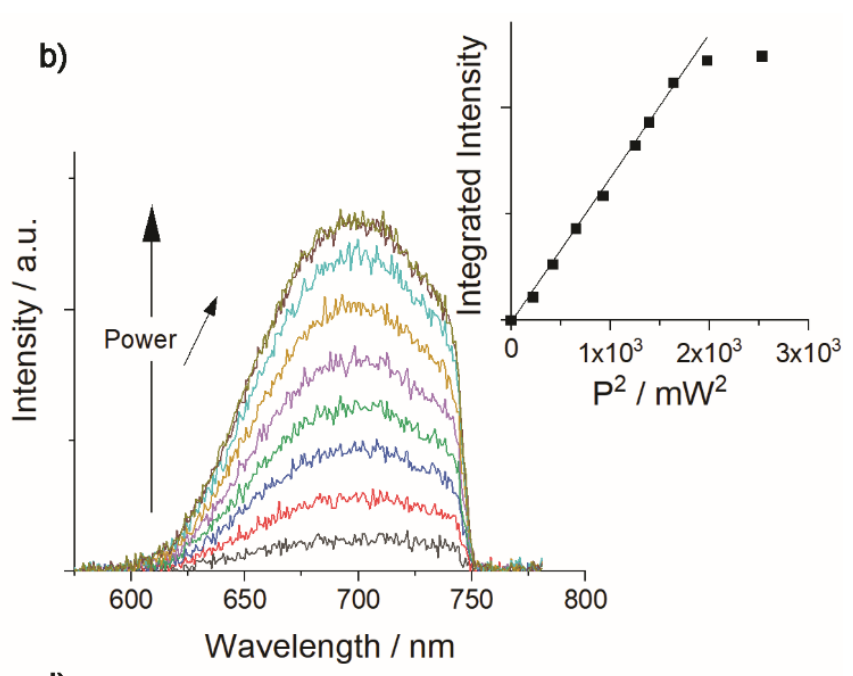

d)

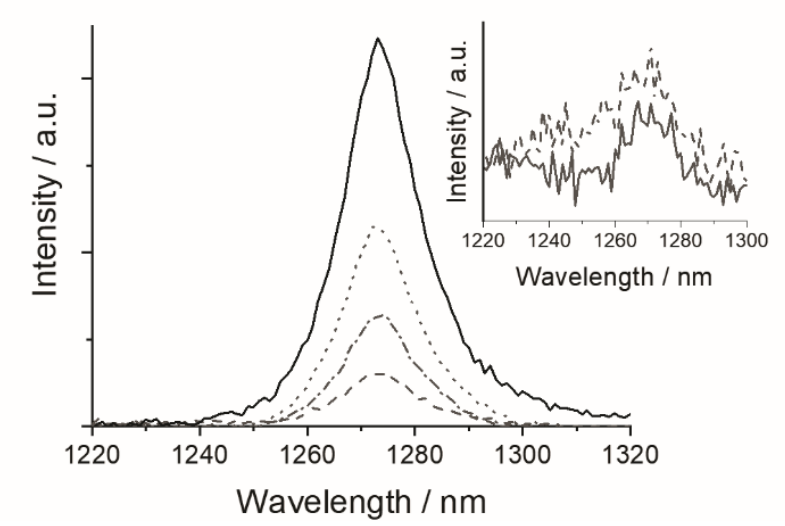

Figure 2. $2 \mathrm{PE}$ spectra $v s$ irradiation power of a) $\mathrm{Cs}_{2} \mathrm{Mo}_{6} \mathrm{i}_{8}\left(\mathrm{OCOC}_{2} \mathrm{~F}_{5}\right)_{6}^{\mathrm{a}}$ in deaerated acetone and b) PDMS10 (spectra are cut at $750 \mathrm{~nm}$ because of the $750 \mathrm{~nm}$ short-pass optical filter used to prevent detector damages); inset : quadratic relationship of the observed two-photon emission intensity with the excitation laser power at $790 \mathrm{~nm}$; c) one-photon (plain line, $\lambda_{\text {exc }}=405 \mathrm{~nm}$, no optical filter) and two-photon (dashed line, $\lambda_{\mathrm{exc}}=810 \mathrm{~nm}$, with optical filter : the sharp signal at $810 \mathrm{~nm}$ is the residual excitation band $)$ of $\mathrm{Cs}_{2} \mathrm{Mo}_{6} \mathrm{I}_{8}{ }_{8}\left(\mathrm{OCOC}_{2} \mathrm{~F}_{5}\right)^{\mathrm{a}}{ }_{6}$ in deaerated acetone, inset : corresponding two-photon absorption cross section values $v s$ excitation wavelength; d) singlet oxygen $\left({ }^{1} \Delta_{\mathrm{g}}\right)$ emission spectra obtained by excitation at $375 \mathrm{~nm}$ of powdered $\mathrm{Cs}_{2} \mathrm{Mo}_{6} \mathrm{I}_{8}{ }_{8}\left(\mathrm{OCOC}_{2} \mathrm{~F}_{5}\right)_{6}^{\mathrm{a}}$ (plain line), PDMS10 (dashed line), PDMS5 (dotted line) and PDMS1 (dashed-dotted line); inset: $\mathrm{O}_{2}\left({ }^{1} \Delta_{\mathrm{g}}\right)$ spectra obtained by excitation at $850 \mathrm{~nm}$ for powdered $\mathrm{Cs}_{2} \mathrm{Mo}_{6} \mathrm{I}_{8}{ }_{8}\left(\mathrm{OCOC}_{2} \mathrm{~F}_{5}\right)^{\mathrm{a}}{ }_{6}$ (plain line) and PDMS10 (dashed line). 
In conclusion, we show in this work that octahedral molybdenum clusters are able to emit NIR light by a two-photon absorption process. This ability is observed in solution as well as in the solid state or once metal nanoclusters are embedded homogeneously at various concentrations in a PDMS matrix. We could also evidence that irradiation in the NIR of these materials generates singlet oxygen, of particular importance for PDT. This study, by expanding the toolbox of octahedral transition metal clusters, increases strongly their already high potential in the field bioimaging and PDT. It opens the way to the development of new tools for cancer detection and treatment.

\section{ASSOCIATED CONTENT}

Supporting Information. The following file is available free of charge. Synthesis and analytical details, IR spectra, TGA and DSC thermograms, emission and excitation spectra, emission decays, 2PE photophysical set-up description, and quadratic dependence of powdered $\mathrm{Cs}_{2} \mathrm{Mo}_{6} \mathrm{I}_{8}{ }_{8}\left(\mathrm{OCOC}_{2} \mathrm{~F}_{5}\right)_{6}^{\mathrm{a}}{ }_{6}$ emission intensity $v s$ excitation power (PDF).

\section{AUTHOR INFORMATION}

\section{Corresponding Author}

*yann.molard@univ-rennes1.fr.

\section{Author Contributions}

The manuscript was written through contributions of all authors. All authors have given approval to the final version of the manuscript.

\section{Funding Sources}

SK thanks ANR Renoir for financial support. 


\section{ACKNOWLEDGMENT}

The Centre Regional de Mesures Physiques de l'Ouest (CRMPO) is acknowledged for providing NMR spectroscopy, mass spectrometry and elemental analysis. F. Gouttefangeas and L. Joanny from CMEBA are acknowledged for SEM and EDS analysis.

\section{REFERENCES}

1. Cotton, F. A., Metal Atom Clusters in Oxide Systems. Inorg. Chem. 1964, 3 (9), $1217-$ 1220.

2. Mikhaylov, M. A.; Sokolov, M. N., Molybdenum Iodides - from Obscurity to Bright Luminescence. Eur. J. Inorg. Chem. 2019, 2019 (39-40), 4181-4197.

3. Dierre, B.; Costuas, K.; Dumait, N.; Paofai, S.; Amela-Cortes, M.; Molard, Y.; Grasset, F.; Cho, Y.; Takahashi, K.; Ohashi, N.; Uchikoshi, T.; Cordier, S., Mo6 cluster-based compounds for energy conversion applications: comparative study of photoluminescence and cathodoluminescence. Sci. Technol. Adv. Mater. 2017, 18 (1), 458-466.

4. Kirakci, K.; Kubát, P.; Fejfarová, K.; Martinčík, J.; Nikl, M.; Lang, K., X-ray Inducible Luminescence and Singlet Oxygen Sensitization by an Octahedral Molybdenum Cluster Compound: A New Class of Nanoscintillators. Inorg. Chem. 2016, 55 (2), 803-809.

5. Maverick, A. W.; Najdzionek, J. S.; MacKenzie, D.; Nocera, D. G.; Gray, H. B., Spectroscopic, electrochemical, and photochemical properties of molybdenum(II) and tungsten(II) halide clusters. J. Am. Chem. Soc. 1983, 105 (7), 1878-1882.

6. Fujii, S.; Tanioka, E.; Sasaki, K.; Horiguchi, T.; Akagi, S.; Kitamura, N., ProtonSwitched Emission Behavior of Hexanuclear Molyb-denum(II) Clusters Bearing Terminal Pyridine Carboxylate Ligands. Eur. J. Inorg. Chem. 2020, 2020 (31), 2983-2989. 
7. Brandhonneur, N.; Boucaud, Y.; Verger, A.; Dumait, N.; Molard, Y.; Cordier, S.; Dollo, G., Molybdenum cluster loaded PLGA nanoparticles as efficient tools against epithelial ovarian cancer. Int. J. Pharm. 2021, 592, 120079.

8. Brandhonneur, N.; Hatahet, T.; Amela-Cortes, M.; Molard, Y.; Cordier, S.; Dollo, G., Molybdenum cluster loaded PLGA nanoparticles: An innovative theranostic approach for the treatment of ovarian cancer. Eur. J. Pharm. Biopharm. 2018, 125, 95-105.

9. Solovieva, A. O.; Vorotnikov, Y. A.; Trifonova, K. E.; Efremova, O. A.; Krasilnikova, A. A.; Brylev, K. A.; Vorontsova, E. V.; Avrorov, P. A.; Shestopalova, L. V.; Poveshchenko, A. F.; Mironov, Y. V.; Shestopalov, M. A., Cellular internalisation, bioimaging and dark and photodynamic cytotoxicity of silica nanoparticles doped by $\left\{\mathrm{Mo}_{6} \mathrm{I}_{8}\right\}^{4+}$ metal clusters. J. Mater. Chem. B 2016, 4 (28), 4839-4846.

10. Huby, N.; Bigeon, J.; Lagneaux, Q.; Amela-Cortes, M.; Garreau, A.; Molard, Y.; Fade, J.; Desert, A.; Faulques, E.; Beche, B.; Duvail, J.-L.; Cordier, S., Facile design of red-emitting waveguides using hybrid nanocomposites made of inorganic clusters dispersed in SU8 photoresist host. Opt. Mater. 2016, 52, 196-202.

11. Molard, Y.; Labbe, C.; Cardin, J.; Cordier, S., Sensitization of $\mathrm{Er}^{3+}$ Infra red Photoluminescence embedded in an Hybrid Organic-Inorganic Copolymer containing Octahedral Molybdenum Clusters. Adv. Funct. Mater. 2013, 23 (38), 4821-4825.

12. Wood, S. M.; Prevot, M.; Amela-Cortes, M.; Cordier, S.; Elston, S. J.; Molard, Y.; Morris, S. M., Polarized Phosphorescence of Isotropic and Metal-Based Clustomesogens Dispersed into Chiral Nematic Liquid Crystalline Films. Adv. Opt. Mater. 2015, 3 (10), 13681372. 
13. Molard, Y., Clustomesogens: Liquid Crystalline Hybrid Nanomaterials Containing Functional Metal Nanoclusters. Acc. Chem. Res. 2016, 49 (8), 1514-1523.

14. Ferreira Molina, E.; Martins de Jesus, N. A.; Paofai, S.; Hammer, P.; Amela-Cortes, M.; Robin, M.; Cordier, S.; Molard, Y., When a Red-NIR-Emissive $\mathrm{Cs}_{2}\left[\mathrm{Mo}_{6} \mathrm{Br}_{14}\right]$ Interacts with an Active Diureasil-PEO Matrix: Design of Tunable and White-Light-Emitting Hybrid Material. Chem. Eur. J. 2019, 25 (67), 15248-15251.

15. Robin, M.; Dumait, N.; Amela-Cortes, M.; Roiland, C.; Harnois, M.; Jacques, E.; Folliot, H.; Molard, Y., Direct Integration of Red-NIR Emissive Ceramic-like $\mathrm{A}_{n} \mathrm{M}_{6} \mathrm{X}_{8} \mathrm{X}^{\mathrm{a}}{ }_{6}$ Metal Cluster Salts in Organic Copolymers Using Supramolecular Interactions. Chem. Eur. J. 2018, 24 (19), 4825-4829.

16. Khlifi, S.; Bigeon, J.; Amela-Cortes, M.; Dumait, N.; Loas, G. h.; Cordier, S.; Molard, Y., Switchable Two-Dimensional Waveguiding Abilities of Luminescent Hybrid Nanocomposites for Active Solar Concentrators. ACS Appl. Mater. Interfaces 2020, 12 (12), $14400-14407$.

17. Zhao, Y.; Lunt, R. R., Transparent Luminescent Solar Concentrators for Large-Area Solar Windows Enabled by Massive Stokes-Shift Nanocluster Phosphors. Adv. Energy Mater. 2013, $3(9), 1143-1148$.

18. Khlifi, S.; Fournier Le Ray, N.; Paofai, S.; Amela-Cortes, M.; Akdas-Kilic, H.; Taupier, G.; Derien, S.; Cordier, S.; Achard, M.; Molard, Y., Self-erasable inkless imprinting using a dual emitting hybrid organic-inorganic material. Mater. Today 2020, 35, 34-41.

19. Amela-Cortes, M.; Paofai, S.; Cordier, S.; Folliot, H.; Molard, Y., Tuned Red NIR phosphorescence of polyurethane hybrid composites embedding metallic nanoclusters for oxygen sensing. Chem. Commun. 2015, 51, 8177-8180. 
20. Ghosh, R. N.; Askeland, P. A.; Kramer, S.; Loloee, R., Optical dissolved oxygen sensor utilizing molybdenum chloride cluster phosphorescence. Appl. Phys. Lett. 2011, 98 (22), $221103 / 1-221103 / 3$.

21. Osborn, D. J., III; Baker, G. L.; Ghosh, R. N., $\mathrm{Mo}_{6} \mathrm{Cl}_{12}$-Incorporated Sol-Gel for Oxygen Sensing Applications. J. Sol-Gel Sci. Technol. 2005, 36 (1), 5-10.

22. Ghosh, R. N.; Baker, G. L.; Ruud, C.; Nocera, D. G., Fiber-optic oxygen sensor using molybdenum chloride cluster luminescence. Appl. Phys. Lett. 1999, 75 (19), 2885-2887.

23. Feliz, M.; Atienzar, P.; Amela-Cortes, M.; Dumait, N.; Lemoine, P.; Molard, Y.; Cordier, S., Supramolecular Anchoring of Octahedral Molybdenum Clusters onto Graphene and their Synergies in the Photocatalytic Water Reduction. Inorg. Chem. 2019, 58 (22), 1544315454.

24. Göppert-Mayer, M., Über Elementarakte mit zwei Quantensprüngen. Ann. Phys. 1931, $401(3), 273-294$.

25. Iliopoulos, K.; Krupka, O.; Gindre, D.; Salle, M., Reversible Two-Photon Optical Data Storage in Coumarin-Based Copolymers. J. Am. Chem. Soc. 2010, 132 (41), 14343-14345.

26. Juvekar, V.; Park, S. J.; Yoon, J.; Kim, H. M., Recent progress in the two-photon fluorescent probes for metal ions. Coord. Chem. Rev. 2021, 427, 213574.

27. Lemercier, G.; Four, M.; Chevreux, S., Two-photon absorption properties of 1,10phenanthroline-based $\mathrm{Ru}(\mathrm{II})$ complexes and related functionalized nanoparticles for potential application in two-photon excitation photodynamic therapy and optical power limiting. Coord. Chem. Rev. 2018, 368, 1-12. 
28. He, G. S.; Tan, L.-S.; Zheng, Q.; Prasad, P. N., Multiphoton Absorbing Materials: Molecular Designs, Characterizations, and Applications. Chem Rev 2008, 108 (4), 1245-1330.

29. Xu, L.; Lin, W.; Huang, B.; Zhang, J.; Long, X.; Zhang, W.; Zhang, Q., The design strategies and applications for organic multi-branched two-photon absorption chromophores with novel cores and branches: a recent review. J. Mater. Chem. C 2021, 9 (5), 1520-1536

30. Pu, S.-C.; Yang, M.-J.; Hsu, C.-C.; Lai, C.-W.; Hsieh, C.-C.; Lin, S. H.; Cheng, Y.-M.; Chou, P.-T., The Empirical Correlation Between Size and Two-Photon Absorption Cross Section of CdSe and CdTe Quantum Dots. Small 2006, 2 (11), 1308-1313.

31. Li, H.; Wang, X.; Ohulchanskyy, T. Y.; Chen, G., Lanthanide-Doped Near-Infrared Nanoparticles for Biophotonics. Adv. Mater. 2021, 33, 2000678.

32. Picot, A.; D'Aléo, A.; Baldeck, P. L.; Grichine, A.; Duperray, A.; Andraud, C.; Maury, O., Long-Lived Two-Photon Excited Luminescence of Water-Soluble Europium Complex: Applications in Biological Imaging Using Two-Photon Scanning Microscopy. J. Am. Chem. Soc. 2008, $130(5), 1532-1533$

33. Eliseeva, S. V.; Bünzli, J.-C. G., Lanthanide luminescence for functional materials and bio-sciences. Chem. Soc. Rev. 2010, 39 (1), 189-227.

34. Dou, Y.-K.; Shang, Y.; He, X.-W.; Li, W.-Y.; Li, Y.-H.; Zhang, Y.-K., Preparation of a Ruthenium-Complex-Functionalized Two-Photon-Excited Red Fluorescence Silicon Nanoparticle Composite for Targeted Fluorescence Imaging and Photodynamic Therapy in Vitro. ACS Appl. Mater. Interfaces 2019, 11 (15), 13954-13963.

35. Yin, S.-Y.; Wang, Z.; Liu, Z.-M.; Yu, H.-J.; Zhang, J.-H.; Wang, Y.; Mao, R.; Pan, M.; Su, C.-Y., Multiresponsive UV-One-Photon Absorption, Near-Infrared-Two-Photon 
Absorption, and $\mathrm{X} / \gamma$-Photoelectric Absorption Luminescence in One [Cu4I4] Compound. Inorg. Chem. 2019, 58 (16), 10736-10742.

36. Publications Office of the European Union, Study on the review of the list of Critical

Raw Materials. Critical Raw Materials Factsheets. EU publication: Luxembourg, 2017, DOI: $10.2873 / 398823$

37. Feliz, M.; Garriga, J. M.; Llusar, R.; Uriel, S.; Humphrey, M. G.; Lucas, N. T.; Samoc, M.; Luther-Davies, B., Synthesis, Structure, and Optical-Limiting Properties of Heterobimetallic $\left[\mathrm{M}_{3} \mathrm{CuS}_{4}\right]$ Cuboidal Clusters $(\mathrm{M}=\mathrm{Mo}$ or $\mathrm{W})$ with Terminal Phosphine Ligands. Inorg. Chem. 2001, 40 (24), 6132-6138.

38. Recatala, D.; Llusar, R.; Barlow, A.; Wang, G.; Samoc, M.; Humphrey, M. G.; Guschin, A. L., Synthesis and optical power limiting properties of heteroleptic $\mathrm{Mo}_{3} \mathrm{~S}_{7}$ clusters. Dalton Trans. 2015, 44 (29), 13163-13172.

39. Garriga, J. M.; Llusar, R.; Uriel, S.; Vicent, C.; Usher, A. J.; Lucas, N. T.; Humphrey, M. G.; Samoc, M., Synthesis and third-order nonlinear optical properties of $\left[\mathrm{Mo}_{3}(\mu 3-\mathrm{S})(\mu 2-\right.$ $\left.\mathrm{S} 2)_{3}\right]^{4+}$ clusters with maleonitriledithiolate, oxalate and thiocyanate ligands. Dalton Trans. 2003, (23), 4546-4551.

40. Hummel, T.; Dutczak, D.; Alekseev, A. Y.; Adamenko, L. S.; Shestopalov, M. A.; Mironov, Y. V.; Enseling, D.; Jüstel, T.; Meyer, H.-J., Photodynamic properties of tungsten iodide clusters incorporated into silicone: $\mathrm{A}_{2}\left[\mathrm{M}_{6} \mathrm{I}_{8} \mathrm{~L}_{6}\right] @$ silicone. RSC Advances 2020, 10 (37), $22257-22263$.

41. Amela-Cortes, M.; Molard, Y.; Paofai, S.; Desert, A.; Duvail, J.-L.; Naumov, N. G.; Cordier, S., Versatility of the ionic assembling method to design highly luminescent PMMA 
nanocomposites containing $\left[\mathrm{M}_{6} \mathrm{Q}_{8}^{\mathrm{i}} \mathrm{L}_{6}^{\mathrm{a}}\right]^{\mathrm{n}-}$ octahedral nano-building blocks. Dalton Trans. 2016, $45(1), 237-245$.

42. Camino, G.; Lomakin, S. M.; Lageard, M., Thermal polydimethylsiloxane degradation. Part 2. The degradation mechanisms. Polymer 2002, 43 (7), 2011-2015.

43. Jackson, J. A.; Newsham, M. D.; Worsham, C.; Nocera, D. G., Efficient singlet oxygen generation from polymers derivatized with hexanuclear molybdenum clusters. Chem. Mater. 1996, $8(2), 558-564$.

44. Warrick, E. L.; Pierce, O. R.; Polmanteer, K. E.; Saam, J. C., Silicone Elastomer Developments 1967-1977. Rubber Chem. Technol. 1979, 52 (3), 437-525.

45. Makarov, N. S.; Drobizhev, M.; Rebane, A., Two-photon absorption standards in the 550-1600 nm excitation wavelength range. Optics Express 2008, 16 (6), 4029-4047.

46. Albota, M. A.; Xu, C.; Webb, W. W., Two-photon fluorescence excitation cross sections of biomolecular probes from 690 to $960 \mathrm{~nm}$. Appl. Opt. 1998, 37 (31), 7352-7356.

47. Yoon, M.-C.; Noh, S. B.; Tsuda, A.; Nakamura, Y.; Osuka, A.; Kim, D., Photophysics of meso- $\beta$ Doubly Linked Ni(II) Porphyrin Arrays: Large Two-Photon Absorption CrossSection and Fast Energy Relaxation Dynamics. J. Am. Chem. Soc. 2007, 129 (33), 1008010081.

48. Zhao, T.; Shen, X.; Li, L.; Guan, Z.; Gao, N.; Yuan, P.; Yao, S. Q.; Xu, Q.-H.; Xu, G. Q., Gold nanorods as dual photo-sensitizing and imaging agents for two-photon photodynamic therapy. Nanoscale 2012, 4 (24), 7712-7719. 
49. Zhang, R.; Yang, L.; Kong, L.; Hai-Yan, W.; Yang, J.-X.; Xu, X.-Y., Two-photon absorbing performance and interfacial coordination enhanced mechanism of TPPA-CdS hybrid. Opt. Mater. 2020, 106, 109986.

50. Szczepura, L. F.; Soto, E., Exploring the Breadth of Terminal Ligands Coordinated in $\left[\mathrm{Mo}_{6} \mathrm{X}_{8}\right]^{4+}$ - and $\left[\mathrm{Re}_{6} \mathrm{Q}_{8}\right]^{2+}$-Based Cluster Complexes. In Ligated Transition Metal Clusters in Solid-state Chemistry : The legacy of Marcel Sergent, Halet, J.-F., Ed. Springer International Publishing: Cham, 2019; pp 75-108.

51. Sun, Z.; Zhang, L.-P.; Wu, F.; Zhao, Y., Photosensitizers for Two-Photon Excited Photodynamic Therapy. Adv. Funct. Mater. 2017, 27 (48), 1704079. 
Supporting Information

\section{Expanding the Toolbox of Octahedral}

\section{Molybdenum Clusters and Nanocomposite}

Made Thereof: Evidence of Two-Photon

\section{Absorption induced -NIR Emission and -Singlet Oxygen Production.}

Soumaya Khlifi, Gregory Taupier, Maria Amela-Cortes, Noée Dumait, Stéphane Freslon,

Stéphane Cordier, Yann Molard*

yann.molard@univ-rennes1.fr 


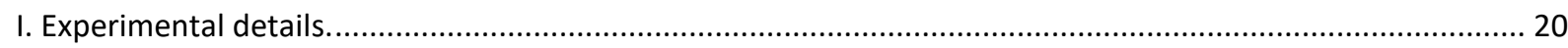

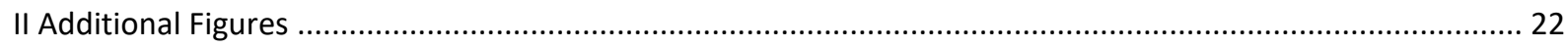

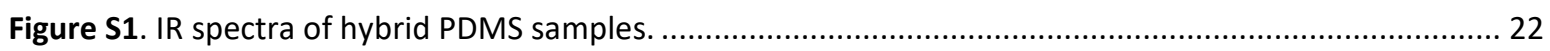

Figure S2. SEM micrographs and related EDS analysis for doped PDMS samples ....................................23

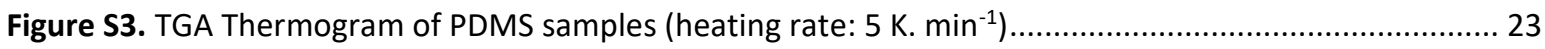

Figure S4. DSC thermograms of PDMS samples showing the second heating cycle at a heating rate of $10 \mathrm{~K}$.

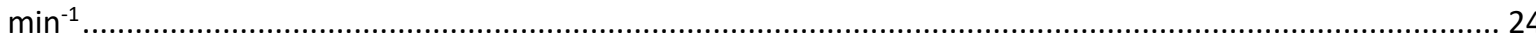

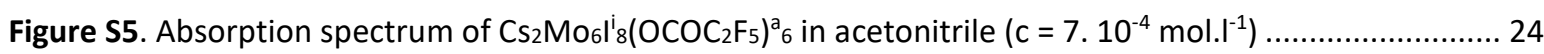

Figure S6. Excitation (in black) and emission (in red) spectra recorded for $\mathrm{Cs}_{2} \mathrm{Mo}_{6} \mathrm{I}_{8}{ }_{8}\left(\mathrm{OCOC}_{2} \mathrm{~F}_{5}\right)_{6}{ }_{6}$ in deaerated acetone.

Figure S7. Excitation (in black) and emission (in red) spectra recorded for $\mathrm{Cs}_{2} \mathrm{Mo}_{6} \mathrm{I}_{8}{ }_{8}\left(\mathrm{OCOC}_{2} \mathrm{~F}_{5}\right)_{6}{ }_{6}$ in powder form

Figure S8. Excitation (in black) and emission (in red) spectra recorded for PDMS1. .................................. 25

Figure S9. Excitation (in black) and emission (in red) spectra recorded for PDMS5. ......................................25

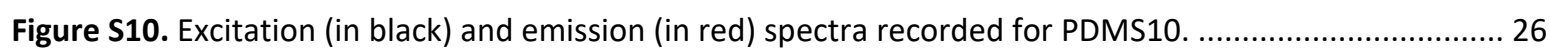

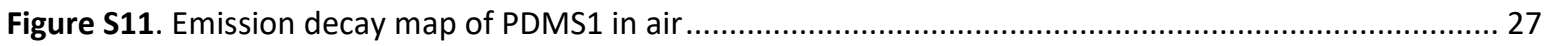

Figure S12. Integrated emission decay profile of PDMS1 in air (in black) and corresponding fitting profile

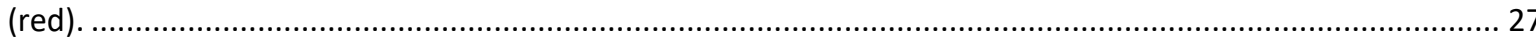

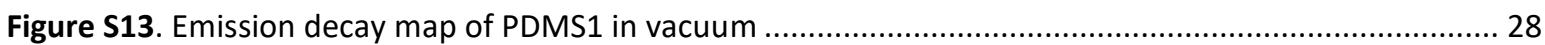

Figure S14. Integrated emission decay profile of PDMS1 in vacuum (in black) and corresponding fitting profile (red).

Figure S15. Emission decay map of PDMS5 in air

Figure S16. Integrated emission decay profile of PDMS5 in air (in black) and corresponding fitting profile (red)

Figure S17. Emission decay map of PDMS5 in vacuum .....

Figure S18. Integrated emission decay profile of PDMS5 in vacuum (in black) and corresponding fitting profile (red)

Figure S19. Emission decay map of PDMS10 in air.

Figure S20. Integrated emission decay profile of PDMS10 in air (in black) and corresponding fitting profile (red)

Figure S21. Emission decay map of PDMS10 after $3 \mathrm{~h}$ in vacuum.

Figure S22. Integrated emission decay profile of PDMS10 after $3 \mathrm{~h}$ in vacuum (in black) and corresponding fitting profile (red).

Figure S23. Schematic presentation of the luminescence measurement set-up used for $1 \mathrm{P}$ and $2 \mathrm{P}$ emission measurements.

Figure S24. Normalized emission spectra ( (left: $\lambda_{\text {exc }}=405 \mathrm{~nm}$, right: $\lambda_{\mathrm{exc}}=810 \mathrm{~nm}$ ) for $\mathrm{Cs}_{2} \mathrm{Mo}_{6} \mathrm{I}_{8}{ }_{8}\left(\mathrm{OCOC}_{2} \mathrm{~F}_{5}\right)^{\mathrm{a}} 6$ in powder (black), in deaerated acetone (red), PDMS1 (blue), PDMS5 (green) and PDMS10 (purple) ..... 33

Figure S25. TPA induced emission spectra of $\mathrm{Cs}_{2} \mathrm{Mo}_{6}{ }_{8}\left(\mathrm{OCOC}_{2} \mathrm{~F}_{5}\right)_{6}$ in the solid state for $\lambda_{\mathrm{exc}}=810 \mathrm{~nm}$ and various excitation power (left); quadratic dependency of 2PA induced emission intensity with excitation power (right, $\lambda_{\text {exc }}=810 \mathrm{~nm}$ ). 


\section{Experimental details.}

Characterization techniques:

- NMR experiments in solution were realized at $298 \mathrm{~K}$ in deuterated solvent with a Bruker Ascend $500 \mathrm{MHz}$ NMR spectrometer. All peaks were referenced to the methyl signals of TMS at $\delta=0 \mathrm{ppm}$.

- TGA were realized in a $\mathrm{N}_{2}$ atmosphere with a Perkin Elmer Pyris Diamond at $5 \mathrm{~K} \mathrm{~min}^{-1}$ up to $700^{\circ} \mathrm{C}$ followed by 1 hour at $700^{\circ} \mathrm{C}$ under air. Weight loss steps and decomposition temperature $\left(\mathrm{T}_{\mathrm{d}}\right.$, Table 1) are taken as the maximum of the weight loss first derivate with temperature.

- DSC measurements were realized at $10 \mathrm{~K} \cdot \mathrm{min}^{-1}$ with a TA25 DSC apparatus.

- IR spectra were obtained with a Bruker Vertex 70 IR spectrometer by ATR.

- EDX were realized in CMEBA-SCanMAT platform with a JEOL IT 300 LA EDS (elemental mapping, acquisition voltage $20 \mathrm{kV}$ ) or with a JSM-7100F equipped with an Oxford X-Max spectrometer.

- Mass spectrometry by electrospray in positive mode and elemental analysis were realized at the Centre Régional des Mesures de l'Ouest (CRMPO) with an Agilent 6510 or a Bricker MaXis 4G and a flash EA1112 CHNS/O Thermo Electron microanalyser, respectively.

- UV-vis absorption measurements, one photon emission vs excitation maps were recorded on a Horiba Jobin Yvon Duetta spectrophotometer.

- The absolute quantum yields were measured with a C9920-03 Hamamatsu system.

- One photon absorption Lifetime measurements and TRPL mapping at $296 \mathrm{~K}$ were realized using a picosecond laser diode (Jobin Yvon deltadiode, $375 \mathrm{~nm}$ ) and a Hamamatsu C10910-25 streak camera mounted with a slow single sweep unit. Signals were integrated on the whole emission decay. Fits were calculated using origin software and the goodness of fit judge by the reduced $\chi^{2}$ value and residual plot shape. $\mathrm{O}_{2}\left({ }^{1} \Delta_{\mathrm{g}}\right)$ measurements were realized with a Hamamatsu H12397-75 NIR-PMT unit mounted on a IHR3 spectrometer.

- Emission spectra by two photon or one photon absorption were recorded using a femtosecond laser chain (Ti-Sapphire Chameleon ultra II Coherent + pulse picker + SHG module when needed) and an Ocean optics QEPro CCD detector with integrating times ranging from 1 to 20s. The excitation beam crossed a longpass $800 \mathrm{~nm}$ optical filter before arriving on the sample and a shortpass $750 \mathrm{~nm}$ filter after the sample to remove the excitation signal and prevent damages on the CCD detector. The power of the beam was measured with a PMD100 console and a S142C integrating sphere sensor from Thorlabs. The shape and size of the beam spot at the focal point is elliptic with an area of $3920 \mu \mathrm{m}^{2}$.

Synthesis: All Chemical were purchased from Aldrich or Alfa Aesar. $\mathrm{Cs}_{2} \mathrm{Mo}_{6} \mathrm{I}_{8}\left(\mathrm{OOCC}_{2} \mathrm{~F}_{5}\right)_{6}$ was synthesized as reported previously with conform analytical data. ${ }^{1}$

\section{Synthesis of the organic cation salt CatBr}

The organic cation is synthesized in two steps according to the following procedures. Step 1:
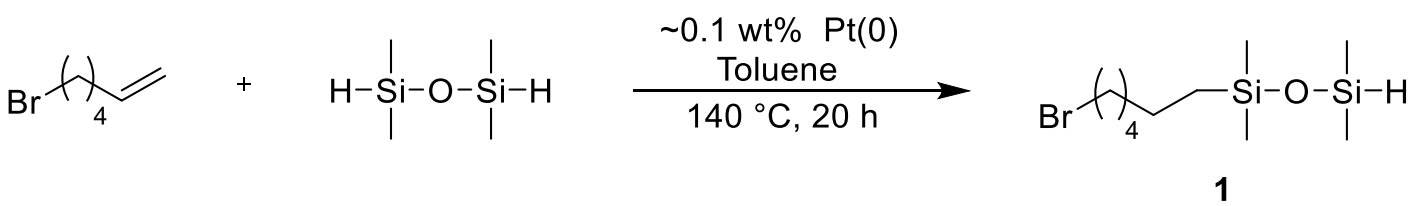

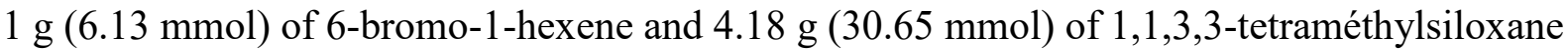
are dissolved in $150 \mathrm{ml}$ of toluene. After addition of a catalytic amount $(5 \mu \mathrm{l})$ of a xylene solution 
containing Platinum (0)-1,3-divinyl-1,1,3,3-tetraméthyldisiloxane (Pt content $\sim 2 \%$ ) the mixture is heated at $140^{\circ} \mathrm{C}$ during $20 \mathrm{~h}$. Solvents and excess of reactant are removed by evaporation yielding quantitatively to the desired product as a pale-yellow oil.

$\underline{\mathrm{RMN}-}{ }^{1} \mathrm{H}\left(300 \mathrm{MHz}, \mathrm{CDCl}_{3}\right): 4.72$ (sept, $\left.1 \mathrm{H}, \mathrm{Si}-\mathrm{H}\right), 3.43$ (t, 2H, $\mathrm{CH}_{2}-\mathrm{Br}$ ), 1.88 (quint, 2H, $\mathrm{CH}_{2}-$ $\left.\mathrm{CH}_{2}-\mathrm{Br}\right), 1.53-1.32\left(\mathrm{~m}, 6 \mathrm{H},\left(\mathrm{CH}_{2}\right)_{3}\right), 0.57$ (m, 2H, $\left.\mathrm{CH}_{2}-\mathrm{Si}\right), 0.20$ (d, 6H, $\left.\left(\mathrm{CH}_{3}\right)_{2}-\mathrm{Si}-\mathrm{H}\right), 0.10$ (s, $\left.6 \mathrm{H},\left(\mathrm{CH}_{3}\right)_{2}-\mathrm{Si}\right)$.

Step 2:
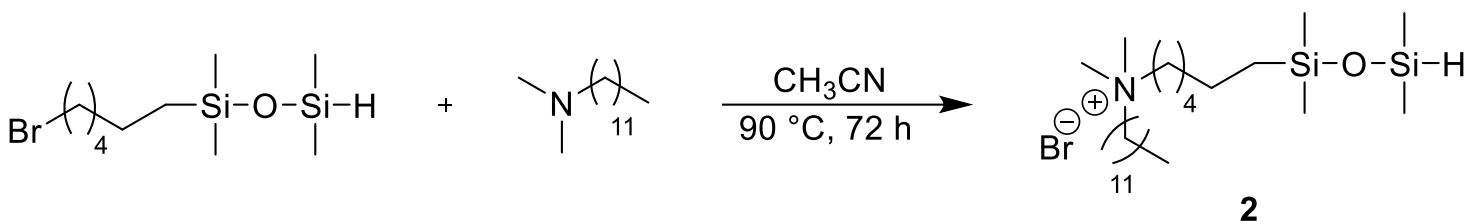

$1.77 \mathrm{~g}$ (5.94 mmol) of 1-(6-bromohexyl)-1,1,3,3-tetramethyldisiloxane (1) and $1.27 \mathrm{~g}$ (5.94 mmol) of N,N-dimethyldodecylamine are dissolved in $100 \mathrm{ml}$ of acetonitrile. The mixture is heated at $90^{\circ} \mathrm{C}$ under stirring during $72 \mathrm{~h}$. After solvent evaporation, the desired compound is obtained as a white powder by precipitation in diethylether at $-18^{\circ} \mathrm{C}$. Yield : $91 \%$.

RMN- ${ }^{1} \mathrm{H}\left(300 \mathrm{MHz}, \mathrm{CDCl}_{3}\right): 4.67$ (sept, $\left.1 \mathrm{H}, \mathrm{Si}-\mathrm{H}\right), 3.45\left(\mathrm{~m}, 4 \mathrm{H},\left(\mathrm{CH}_{2}-\mathrm{N}^{+}\right)_{2}\right), 3.33(\mathrm{~s}, 6 \mathrm{H}$, $\left.\left(\mathrm{CH}_{3}\right)_{2}-\mathrm{N}^{+}\right), 1.62\left(\mathrm{~m}, 4 \mathrm{H},\left(\mathrm{CH}_{2}-\mathrm{CH}_{2}-\mathrm{N}^{+}\right)_{2}\right), 1.44-1.12\left(\mathrm{~m}, 24 \mathrm{H}, 12 \mathrm{CH}_{2}\right), 0.80\left(\mathrm{t}, 3 \mathrm{H}, \mathrm{CH}_{3}\right), 0.44$ (m, 2H, $\left.\mathrm{CH}_{2}-\mathrm{Si}\right), 0.08$ (d, 6H, $\left.\left(\mathrm{CH}_{3}\right)_{2}-\mathrm{Si}-\mathrm{H}\right),-0.02\left(\mathrm{~s}, 6 \mathrm{H},\left(\mathrm{CH}_{3}\right)_{2}-\mathrm{Si}\right)$.

RMN- ${ }^{13} \mathrm{C}\left(100 \mathrm{MHz}, \mathrm{CDCl}_{3}\right): 64.14\left(\mathrm{CH}_{2}-\mathrm{N}^{+}\right), 51.29\left(\mathrm{CH}_{3}-\mathrm{N}^{+}\right), 32.80-16.80\left(\mathrm{CH}_{2}\right), 0.9-(-$ $0.05)\left(\mathrm{CH}_{3}-\mathrm{Si}\right)$.

$\mathrm{MS}\left(\mathrm{ESI}^{+}, \mathrm{CH}_{2} \mathrm{Cl}_{2}\right): \mathrm{m} / \mathrm{z}($ calculated $)=430.3895, \mathrm{~m} / \mathrm{z}($ obtained $)=430.3900$.

E.A. : calculated for $\mathrm{C}_{24} \mathrm{H}_{56} \mathrm{BrNOSi}_{2}+0.5 \mathrm{H}_{2} \mathrm{O}$ : C, 55.46 ; H, 11.05 ; N, 2.69; obtained: C, $55.44 ; \mathrm{H}, 10.94 ; \mathrm{N}, 2.46$.

\section{Synthesis of the polymerizable cluster $\left(\mathrm{Cat}_{2} \mathrm{Mo}_{6} \mathrm{I}_{8}\left(\mathrm{OCOC}_{2} \mathrm{~F}_{5}\right)_{6}{ }_{6}\left(\mathrm{Cat}_{2} \mathrm{Mog}_{6}\right)\right.$ :}

$0.5 \mathrm{~g}(0.17 \mathrm{mmol})$ of $\mathrm{Cs}_{2} \mathrm{Mo}_{6} \mathrm{I}_{8}\left(\mathrm{OOCC}_{2} \mathrm{~F}_{5}\right)_{6}$ are solubilized in $25 \mathrm{ml}$ of anhydrous acetone and left under stirring. After addition of a $10 \mathrm{ml}$ dry acetone solution containing compound $2(0.2 \mathrm{~g}$; $0.39 \mathrm{mmol}$ ), the mixture is left at $23^{\circ} \mathrm{C}$ under stirring for 2 hours. Solvent is evaporated up to dryness and $10 \mathrm{ml}$ of $\mathrm{CH}_{2} \mathrm{Cl}_{2}$ are added to the obtained slurry. The yellow-red solution in which a white powder precipitates is filtered on celite and solvent is evaporated leading quantitatively to the desired product that is further dried under vacuum.

Caution: This compound is reactive and should be used shortly after its synthesis and/or stored at $-40^{\circ} \mathrm{C}$ to prevent the silane groups of $\mathrm{Cat}^{+}$to react with the cluster anion by apical ligand exchange.

RMN- ${ }^{1} \mathrm{H}\left(400 \mathrm{MHz}, \mathrm{CDCl}_{3}\right)$ : 4.69 (sept, 1H, Si-H), 3.44-3.21 (m, 4H, (CH2-N+)2), 3.16 (s, $6 \mathrm{H},(\mathrm{CH} 3) 2-\mathrm{N}+), 1.73(\mathrm{~m}, 4 \mathrm{H},(\mathrm{CH} 2-\mathrm{CH} 2-\mathrm{N}+) 2), 1.45-1.20(\mathrm{~m}, 24 \mathrm{H},(\mathrm{CH} 2) 3$ et $(\mathrm{CH} 2) 9), 0.88$ (t, 3H, CH3), 0.50 (m, 2H, CH2-Si), 0.07 (d, 6H, (CH3)2-Si-H), 0.01 (s, 6H, (CH3)2-Si).

$\mathrm{RMN}-{ }^{19} \mathrm{~F}(375 \mathrm{MHz}, \mathrm{CDCl} 3)$ : -82.21 (s, 3F), -120.22 (s, 2F).

E.A. : calculated for $\mathrm{C}_{66} \mathrm{H}_{104} \mathrm{O}_{14} \mathrm{~N}_{2} \mathrm{~F}_{30} \mathrm{I}_{8} \mathrm{Si}_{4} \mathrm{Mo}_{6}+3 \mathrm{C}_{3} \mathrm{H}_{6} \mathrm{O}$ : C, $25.04 ; \mathrm{H}, 3.42 ; \mathrm{N}, 0.78$; obtained : C, $25.14 ; \mathrm{H}, 3.65 ; \mathrm{N}, 0.60$.

EDX : no cesium. Mo, $15 \%$; I, $18 \%$; F, $58 \%$. 


\section{Hybrid polymer synthesis:}

The freshly prepared polymerizable cluster $(\mathrm{CatSiH})_{2} \mathrm{Mo}_{6} \mathrm{I}_{8}{ }_{8}\left(\mathrm{OCOC}_{2} \mathrm{~F}_{5}\right)_{6}^{\mathrm{a}}{ }_{6}$ is dissolved in $2 \mathrm{ml}$ of acetone and poured in a screwable vial with a mixture of 1,3-divinyltetraméthyldisiloxane (monomer) and 2,4,6,8-tetraméthylcyclotetrasiloxane (cross-linker). After addition of $0.5 \mu 1$ of a xylene solution containing Platinum (0)-1,3-divinyl-1,1,3,3-tetraméthyldisiloxane ( $\mathrm{Pt} \sim 2 \%$ ), the vial is heated at $65^{\circ} \mathrm{C}$ in an oven for $48 \mathrm{~h}$ to give homogeneous and transparent copolymer pellets.

Amounts of each component are gathered in the following table:

\begin{tabular}{llll}
\hline Sample & $(\mathrm{CatSiH})_{2} \mathrm{Mo}_{6} \mathrm{I}_{8}{ }_{8}\left(\mathrm{OCOC}_{2} \mathrm{~F}_{5}\right)_{6}^{\mathrm{a}}$ & monomer & crosslinker \\
\hline PDMS & - & $1.20 \mathrm{~g}(60 \%)$ & $0.80 \mathrm{~g}(40 \%)$ \\
\hline PDMS1 & $20 \mathrm{mg}$ & $1.20 \mathrm{~g}(60 \%)$ & $0.78 \mathrm{~g}(39 \%)$ \\
PDMS5 & $100 \mathrm{mg}$ & $1.15 \mathrm{~g}(58 \%)$ & $0.75 \mathrm{~g}(37 \%)$ \\
PDMS10 & $200 \mathrm{mg}$ & $1.10 \mathrm{~g}(55 \%)$ & $0.71 \mathrm{~g}(35 \%)$ \\
\hline
\end{tabular}

\section{Additional Figures}

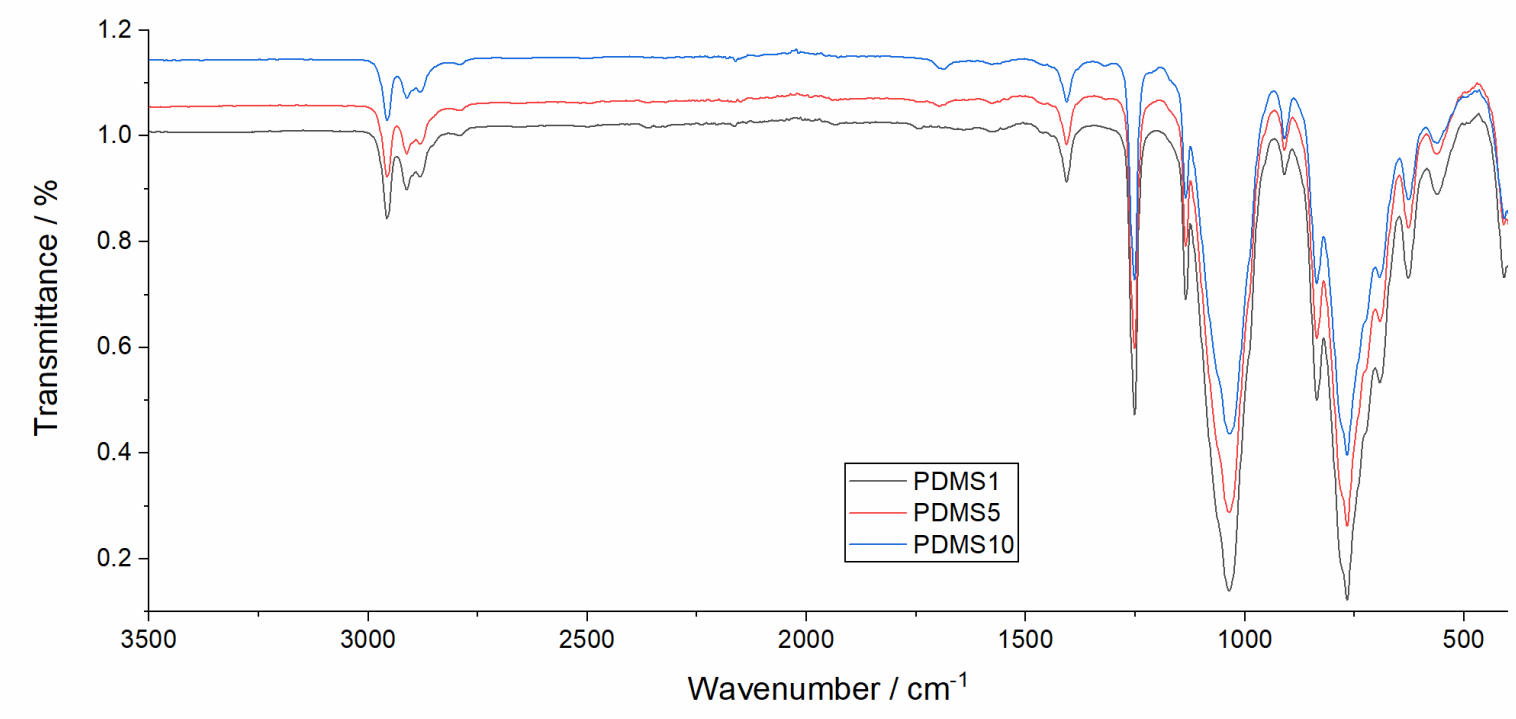

Figure S1. IR spectra of hybrid PDMS samples. 
PDMS1

SEM analysis :

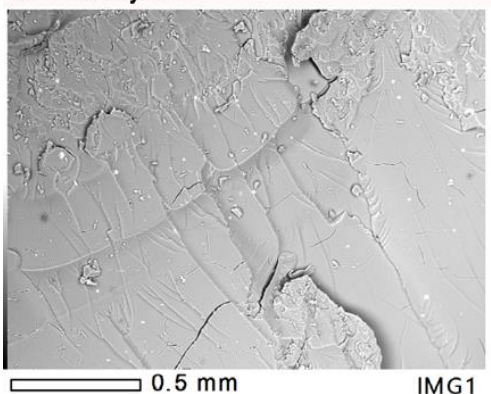

EDS analysis :

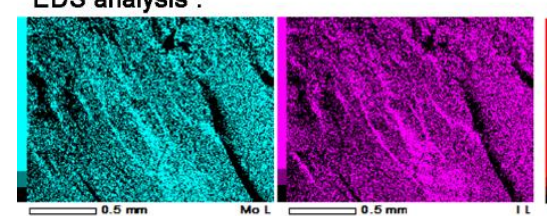

Mo
PDMS5
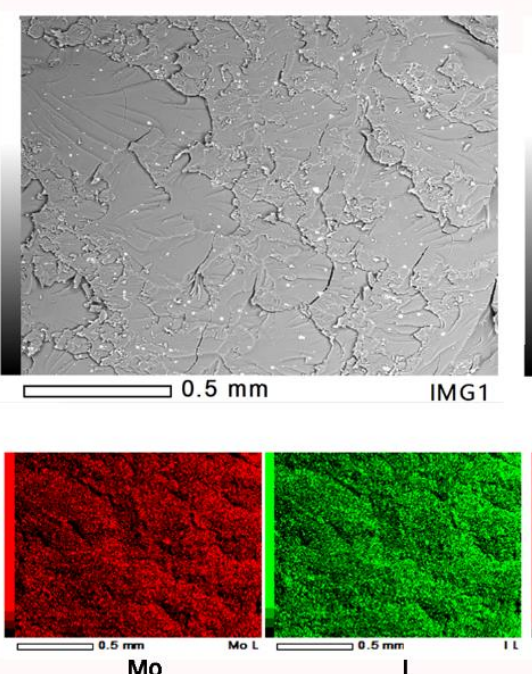

Mo
PDMS10
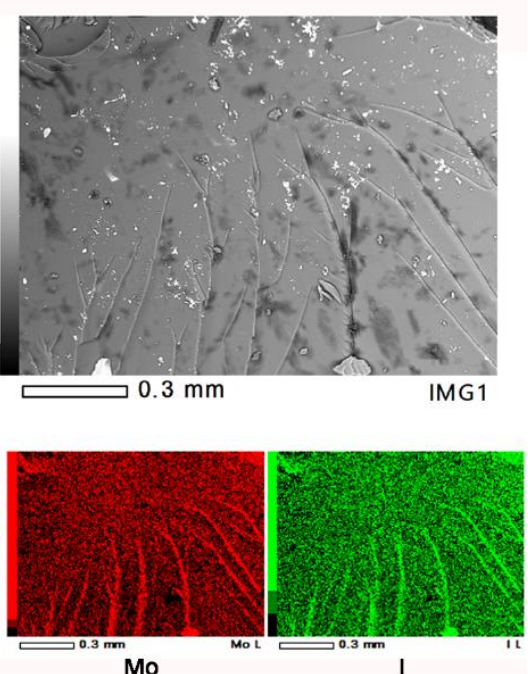

Figure S2. SEM micrographs and related EDS analysis for doped PDMS samples

NB: differences in color are due to the non-planarity of samples.

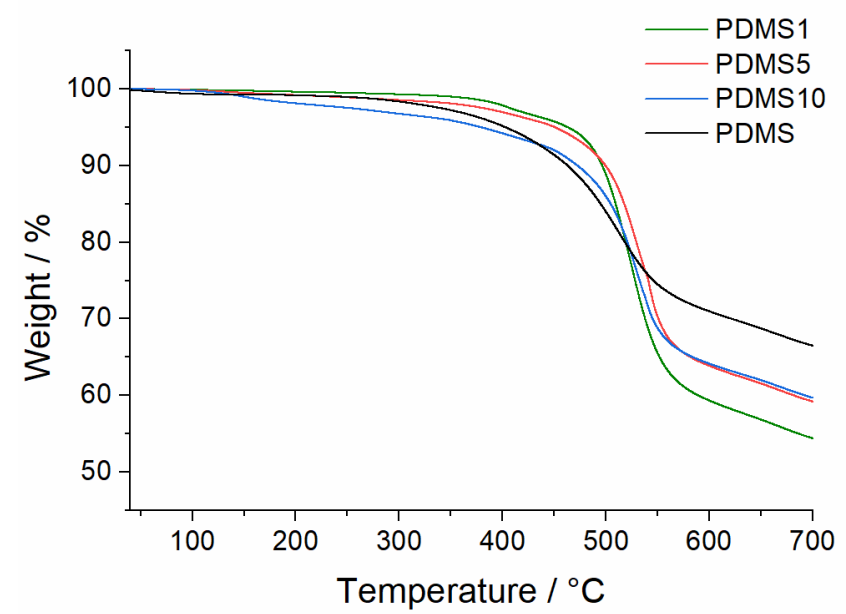

Figure S3. TGA Thermogram of PDMS samples (heating rate: $5 \mathrm{~K} . \mathrm{min}^{-1}$ ) 


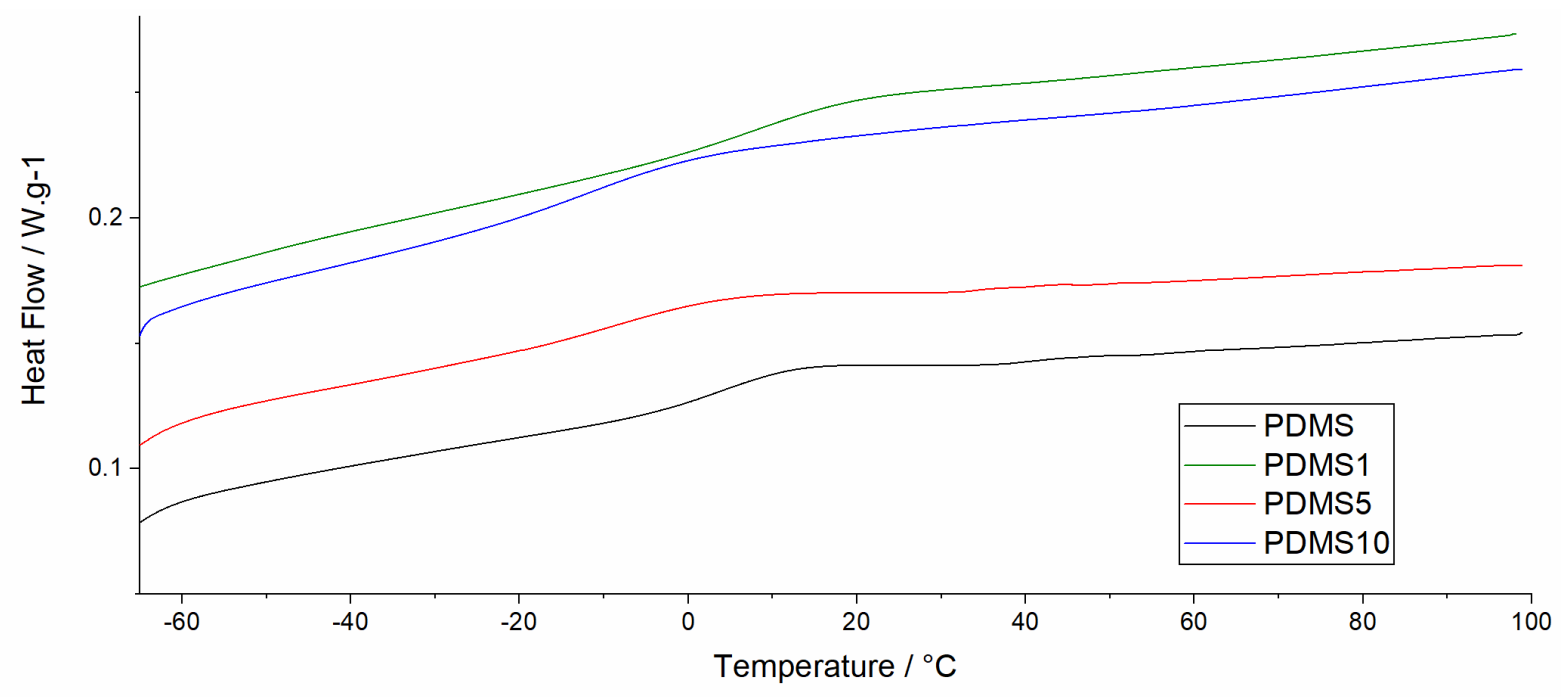

Figure S4. DSC thermograms of PDMS samples showing the second heating cycle at a heating rate of $10 \mathrm{~K} \cdot \mathrm{min}^{-1}$

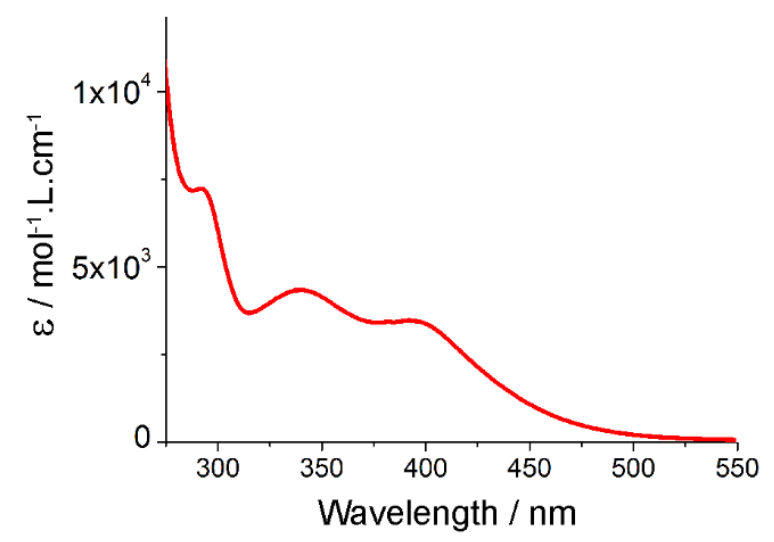

Figure S5. Absorption spectrum of $\mathrm{Cs}_{2} \mathrm{Mo}_{6}{ }_{1}{ }_{8}{ }_{8}\left(\mathrm{OCOC}_{2} \mathrm{~F}_{5}\right)^{\mathrm{a}}{ }_{6}$ in acetonitrile $\left(\mathrm{c}=7 \cdot 10^{-4}\right.$ mol. $\left.\mathrm{l}^{-1}\right)$

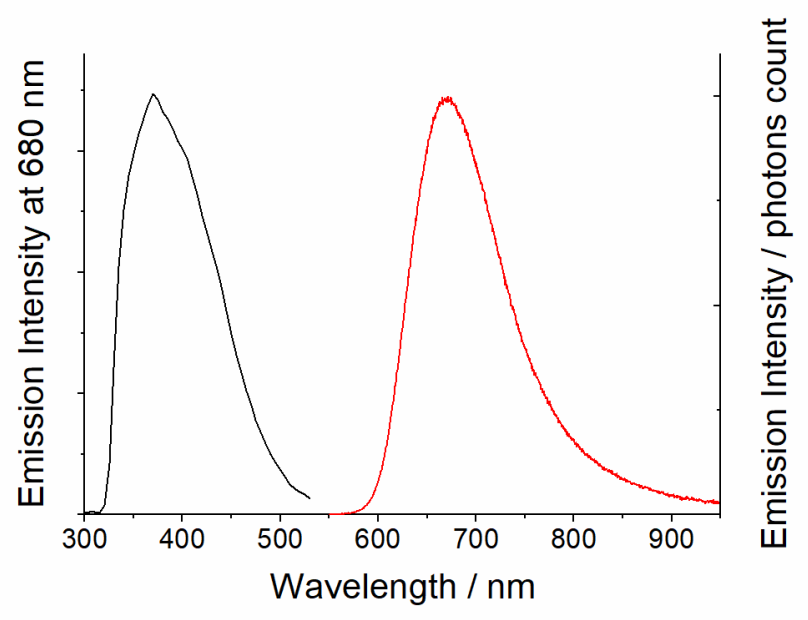

Figure S6. Excitation (in black) and emission (in red) spectra recorded for $\mathrm{Cs}_{2} \mathrm{Mo}_{6} \mathrm{I}_{8}{ }_{8}\left(\mathrm{OCOC}_{2} \mathrm{~F}_{5}\right)_{6}{ }_{6}$ in deaerated acetone. 


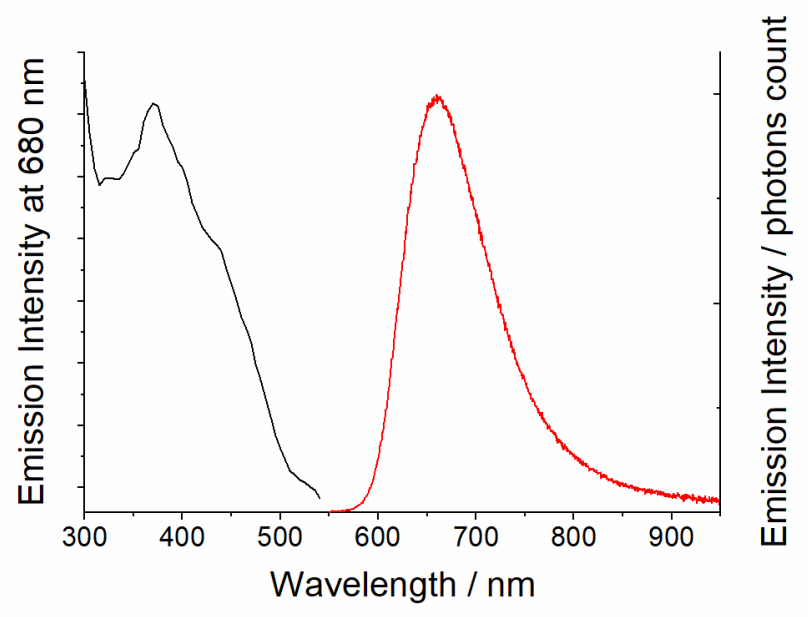

Figure S7. Excitation (in black) and emission (in red) spectra recorded for $\mathrm{Cs}_{2} \mathrm{Mo}_{6} \mathrm{I}_{8}{ }_{8}\left(\mathrm{OCOC}_{2} \mathrm{~F}_{5}\right)_{6}{ }_{6}$ in powder form.

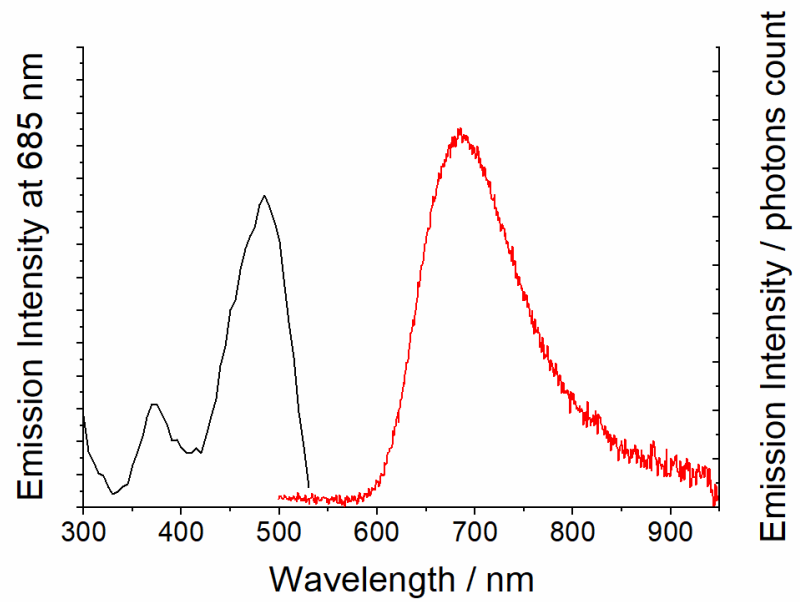

Figure S8. Excitation (in black) and emission (in red) spectra recorded for PDMS1.

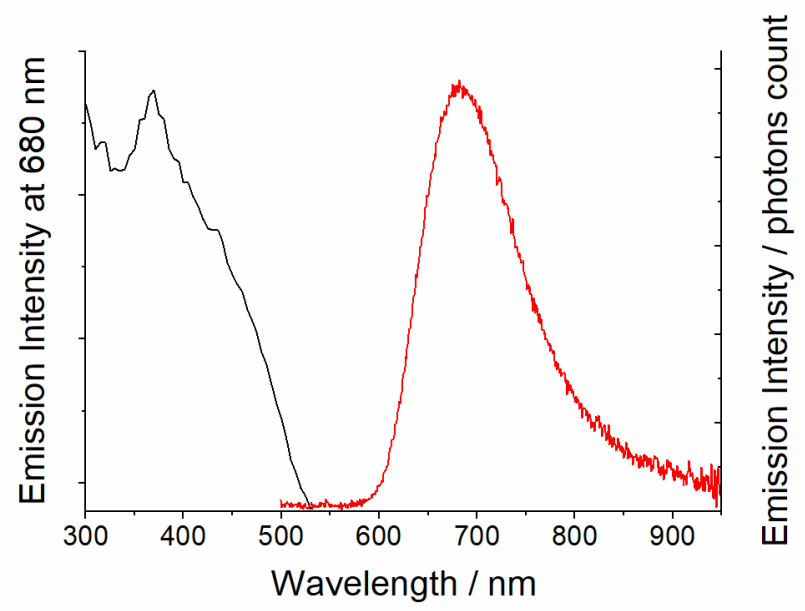

Figure S9. Excitation (in black) and emission (in red) spectra recorded for PDMS5. 


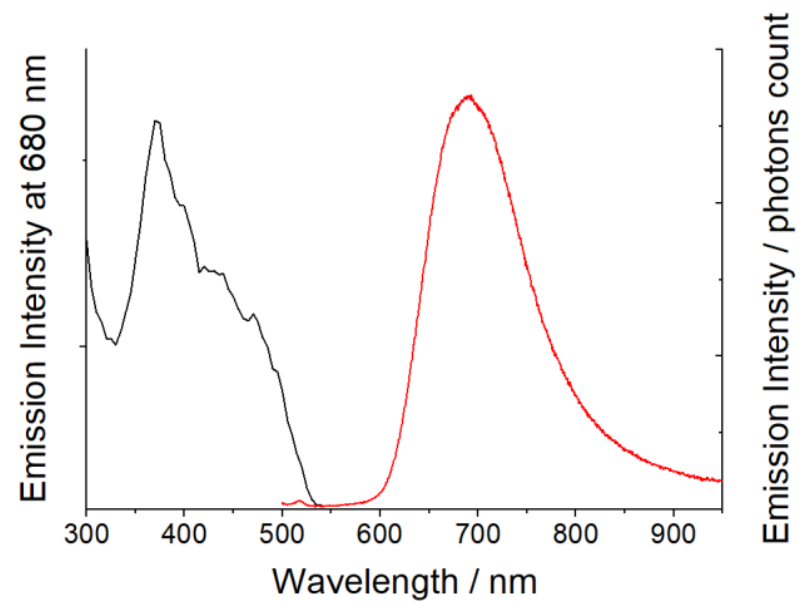

Figure S10. Excitation (in black) and emission (in red) spectra recorded for PDMS10. 


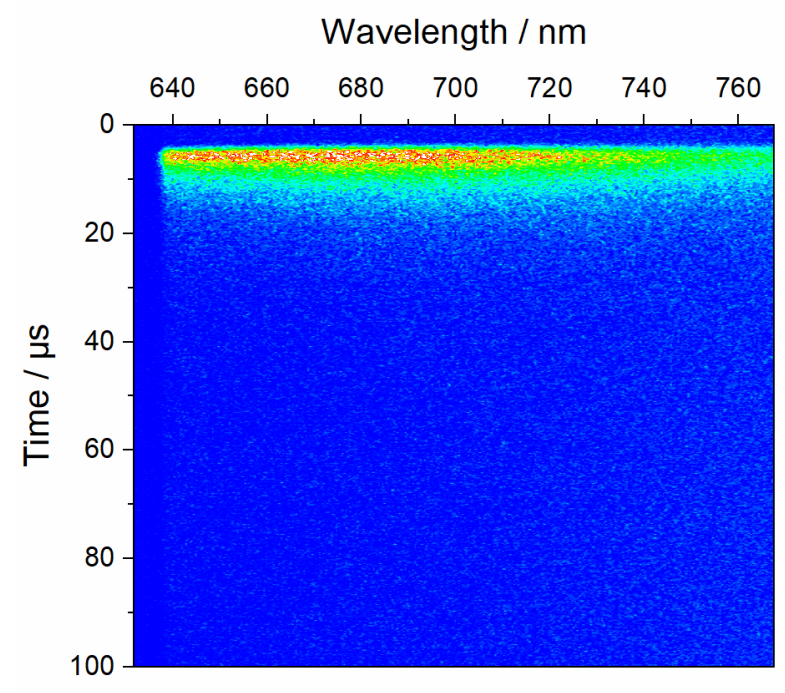

Figure S11. Emission decay map of PDMS1 in air
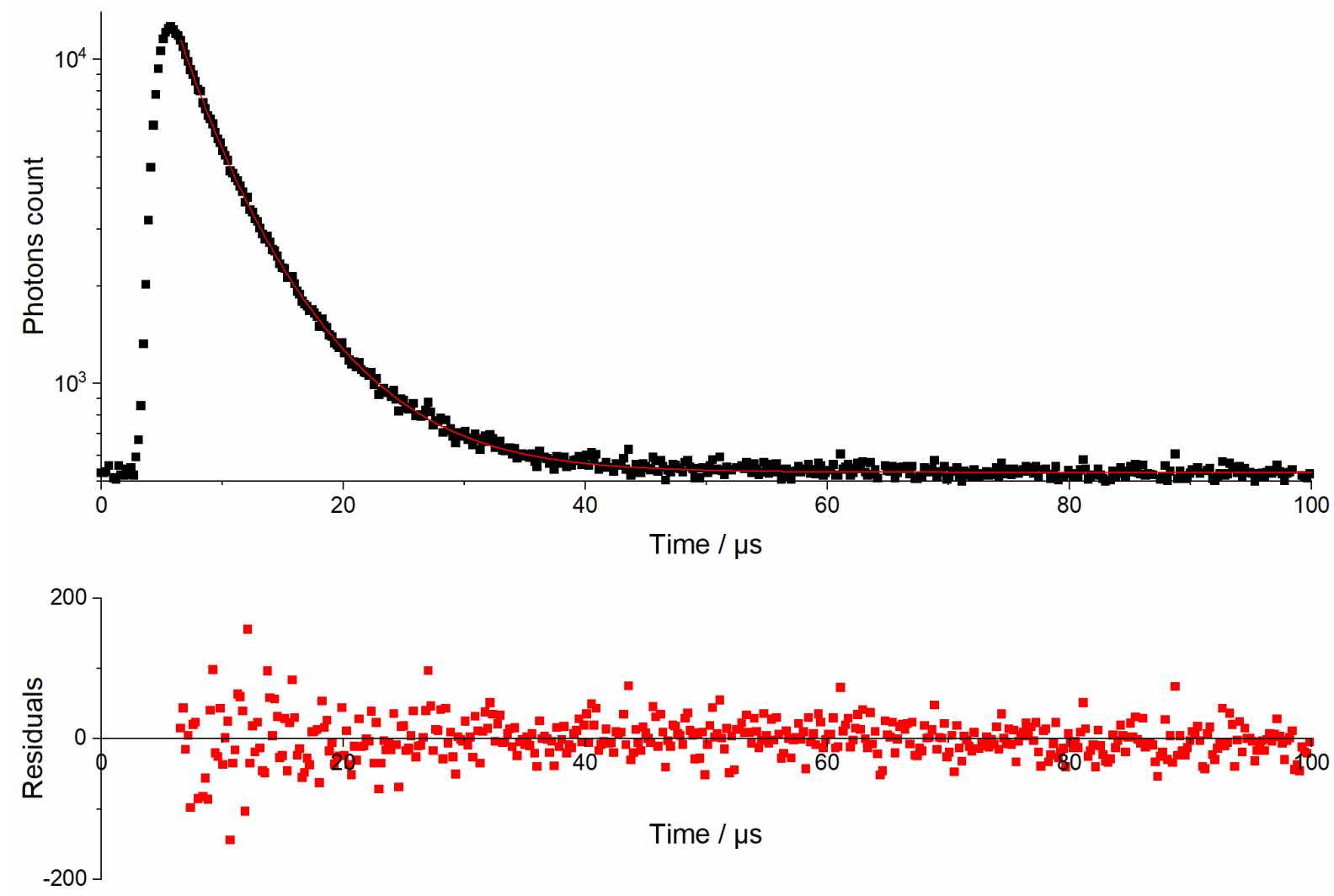

Figure S12. Integrated emission decay profile of PDMS1 in air (in black) and corresponding fitting profile (red). 


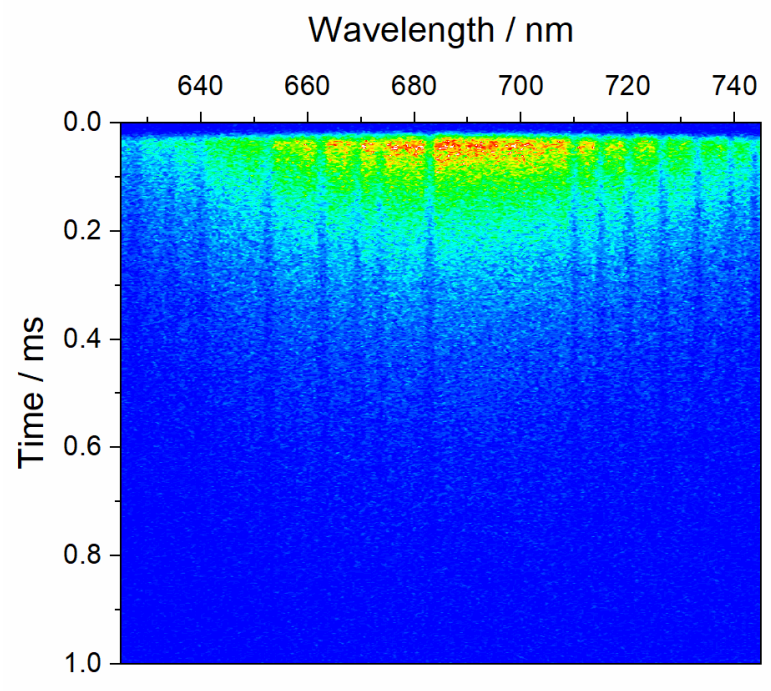

Figure S13. Emission decay map of PDMS1 in vacuum
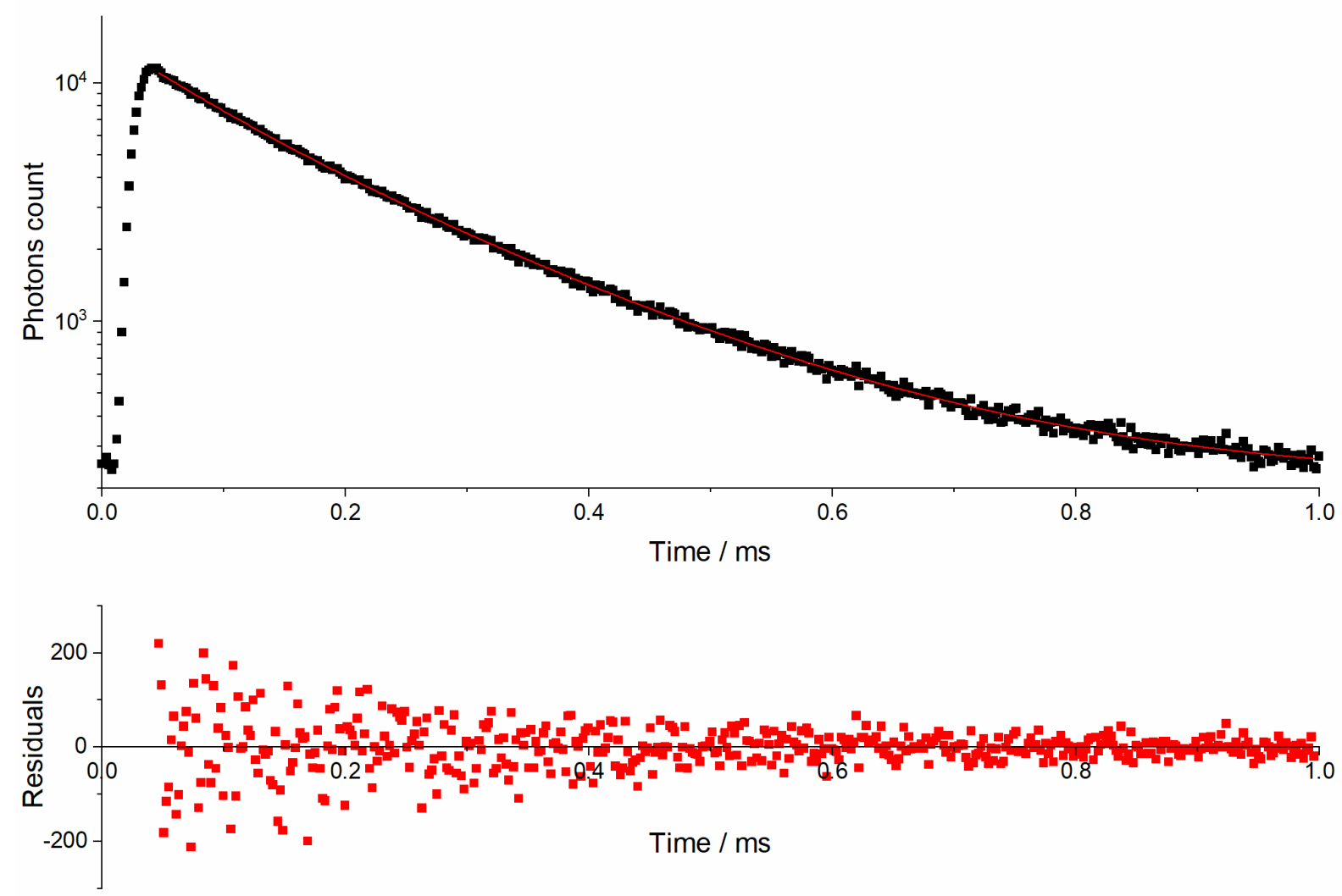

Figure S14. Integrated emission decay profile of PDMS1 in vacuum (in black) and corresponding fitting profile (red). 


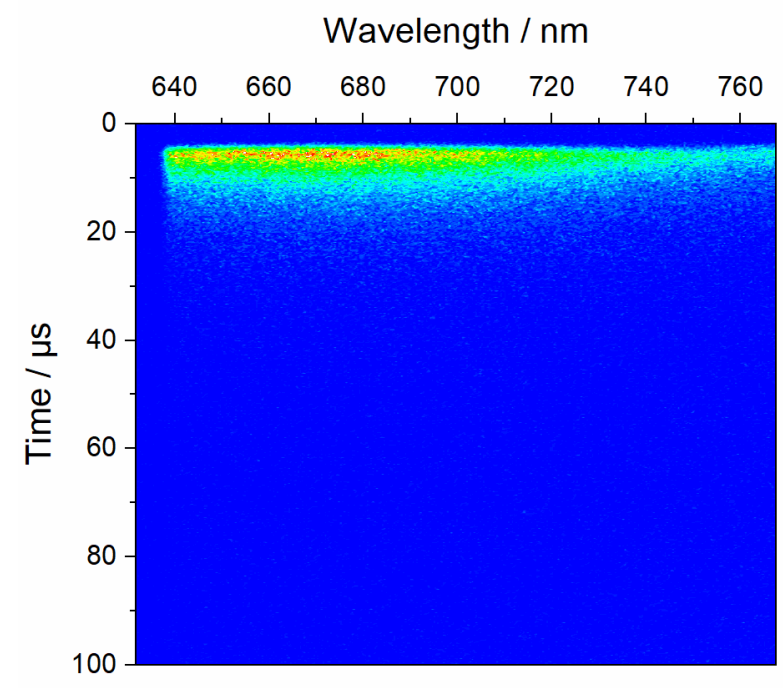

Figure S15. Emission decay map of PDMS5 in air
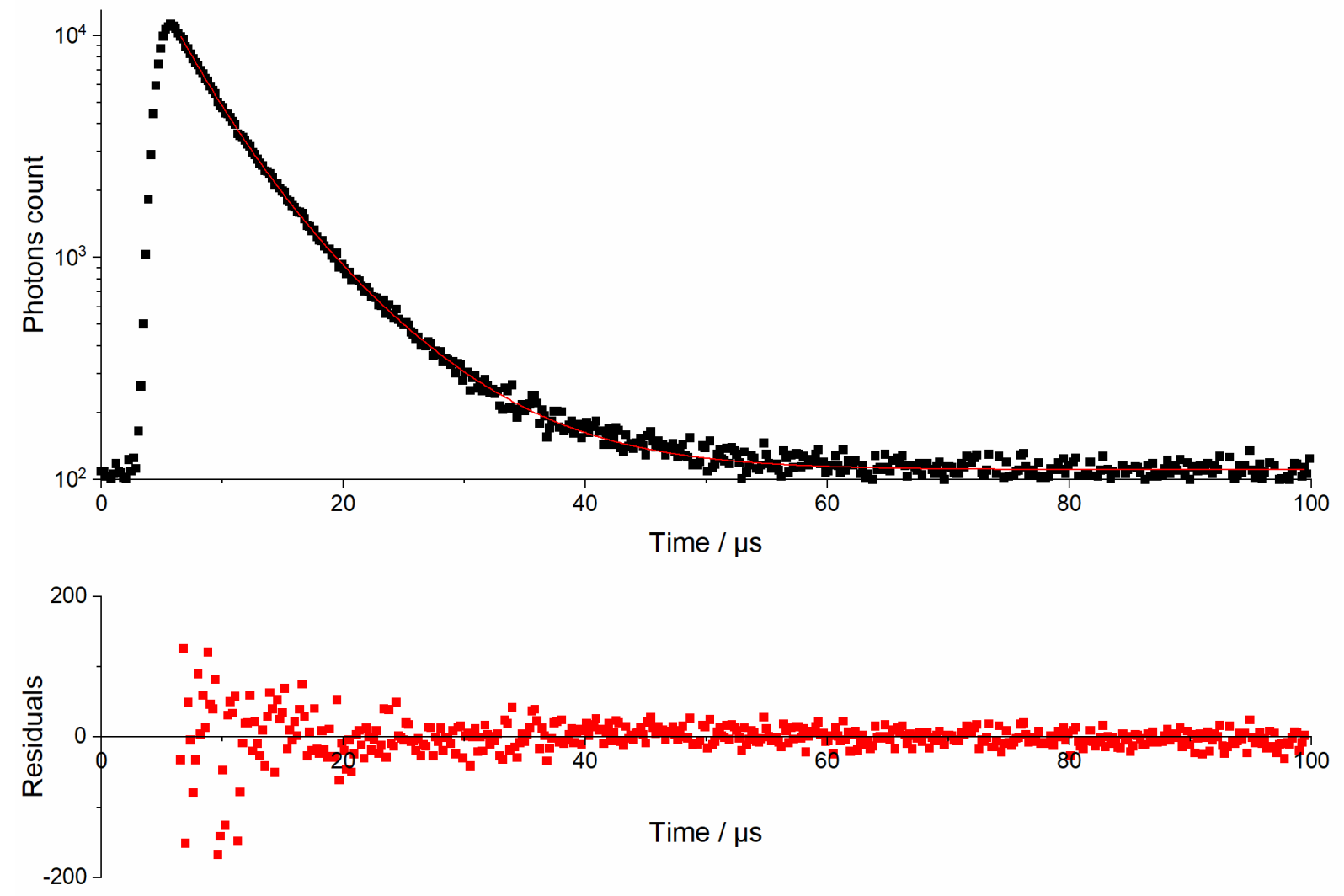

Figure S16. Integrated emission decay profile of PDMS5 in air (in black) and corresponding fitting profile (red) 


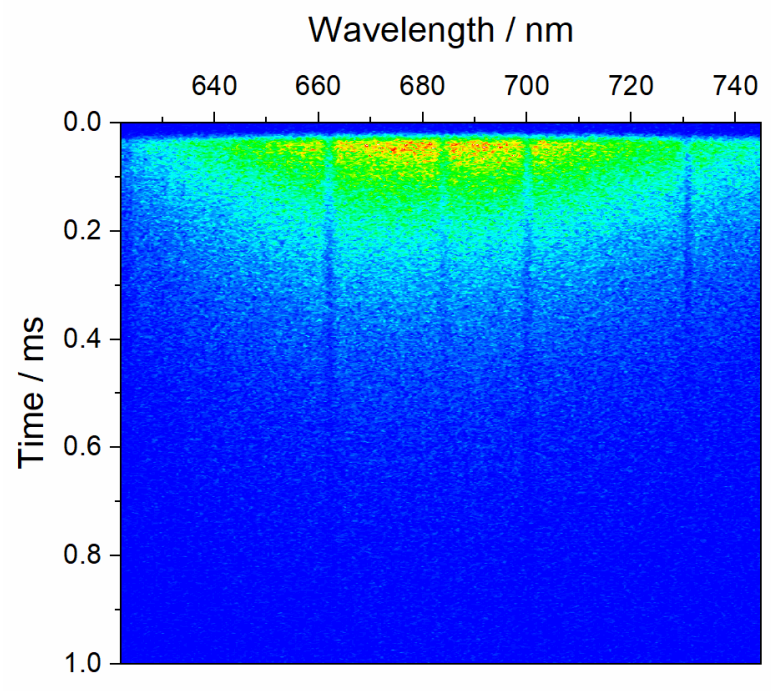

Figure S17. Emission decay map of PDMS5 in vacuum
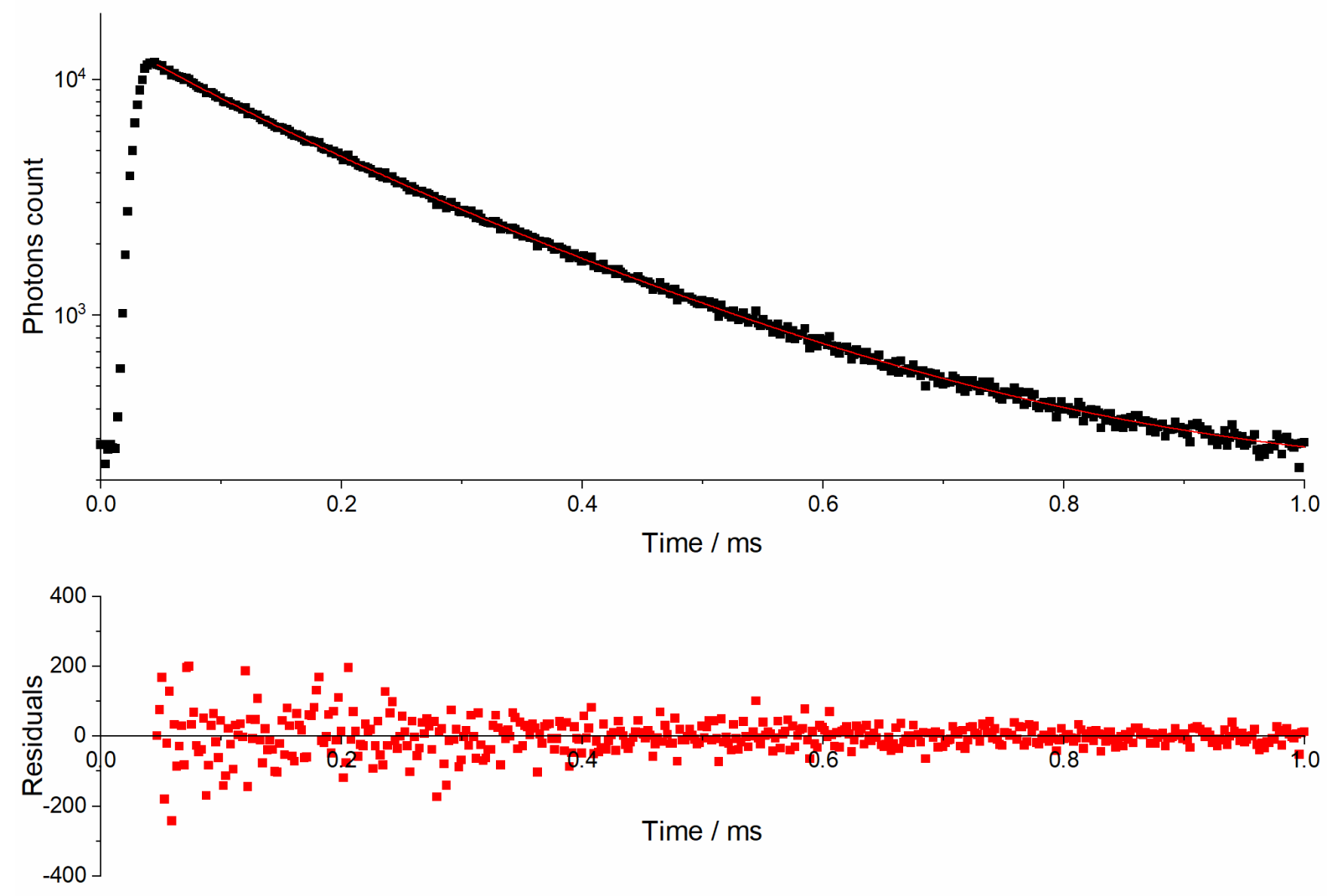

Figure S18. Integrated emission decay profile of PDMS5 in vacuum (in black) and corresponding fitting profile (red) 


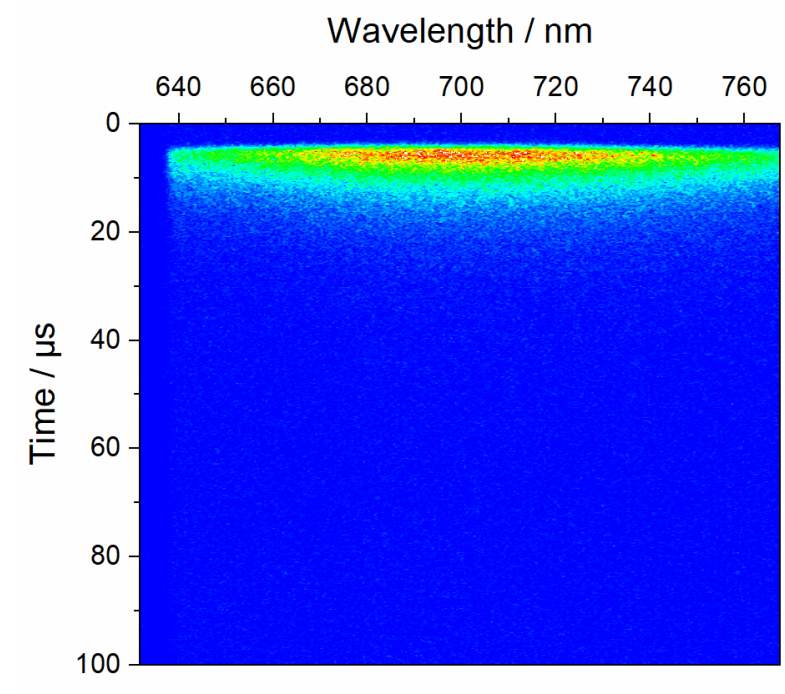

Figure S19. Emission decay map of PDMS10 in air.
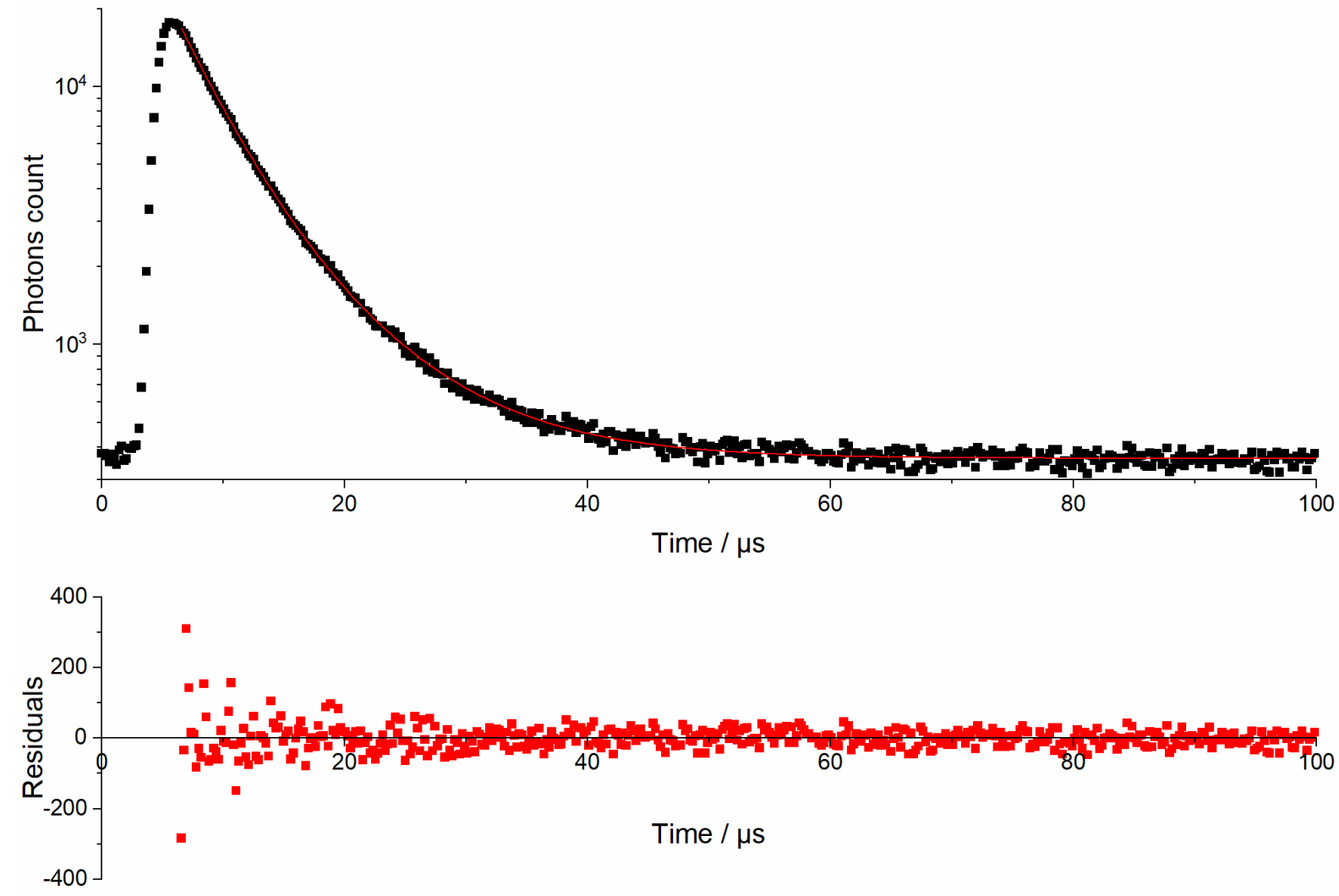

Figure S20. Integrated emission decay profile of PDMS10 in air (in black) and corresponding fitting profile (red) 


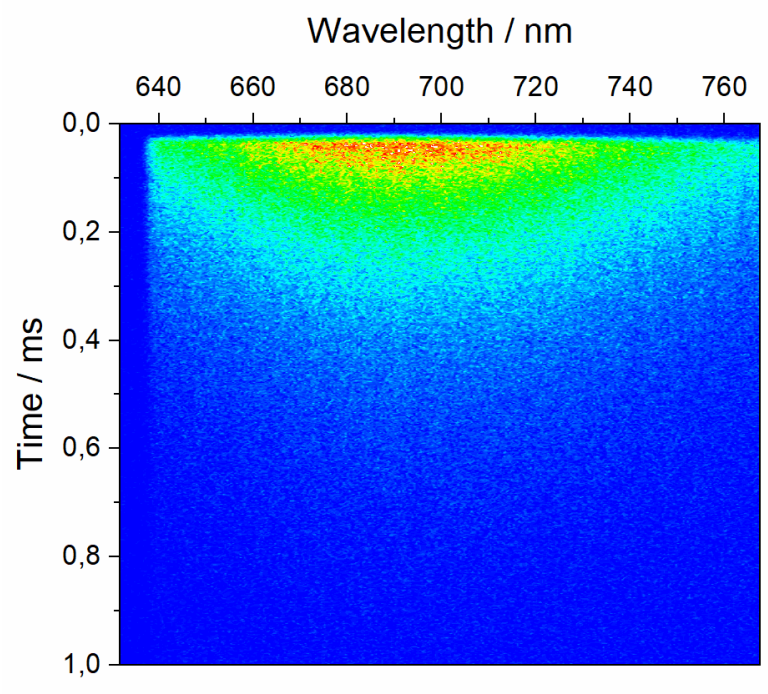

Figure S21. Emission decay map of PDMS10 after 3h in vacuum.
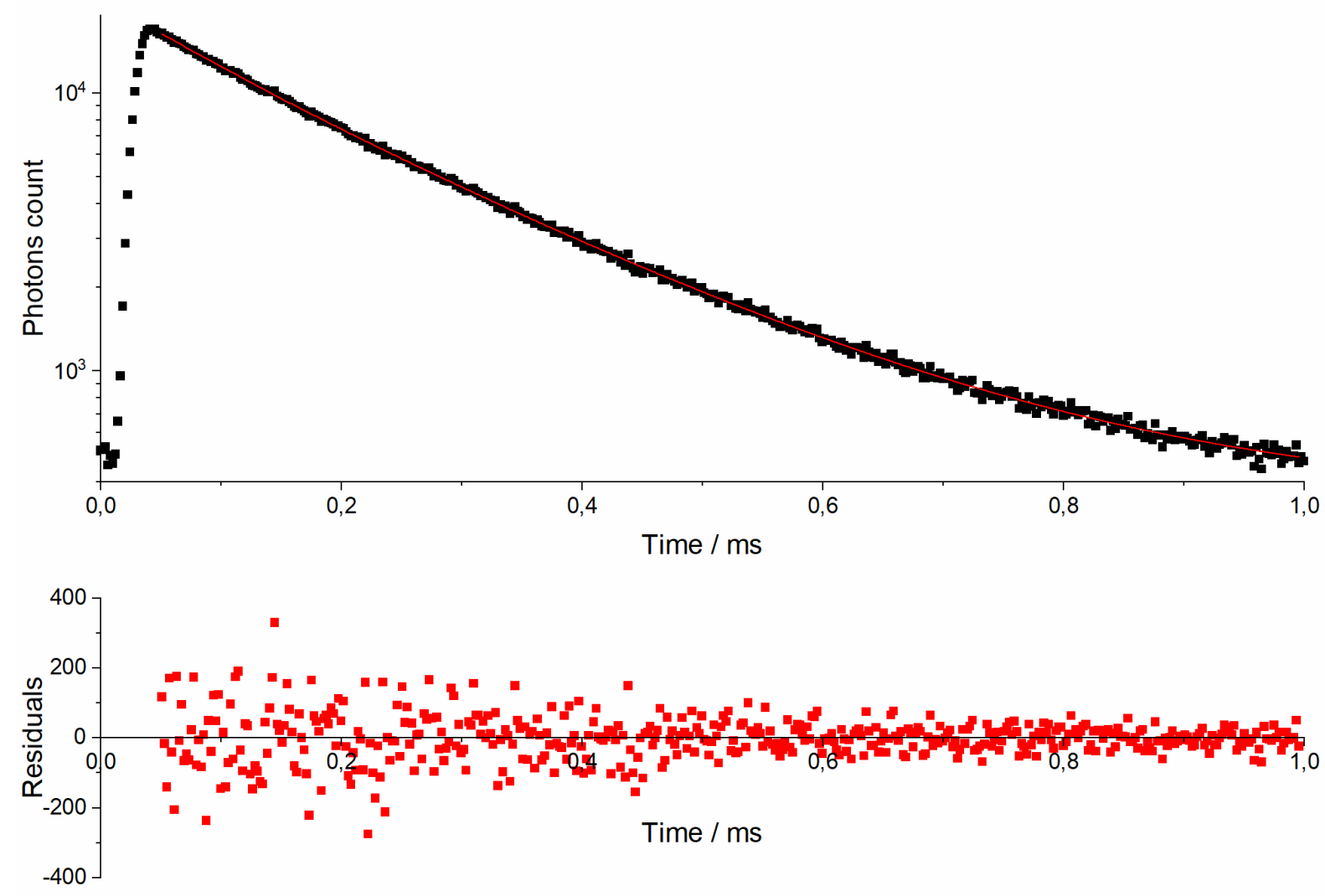

Figure S22. Integrated emission decay profile of PDMS10 after $3 \mathrm{~h}$ in vacuum (in black) and corresponding fitting profile (red). 


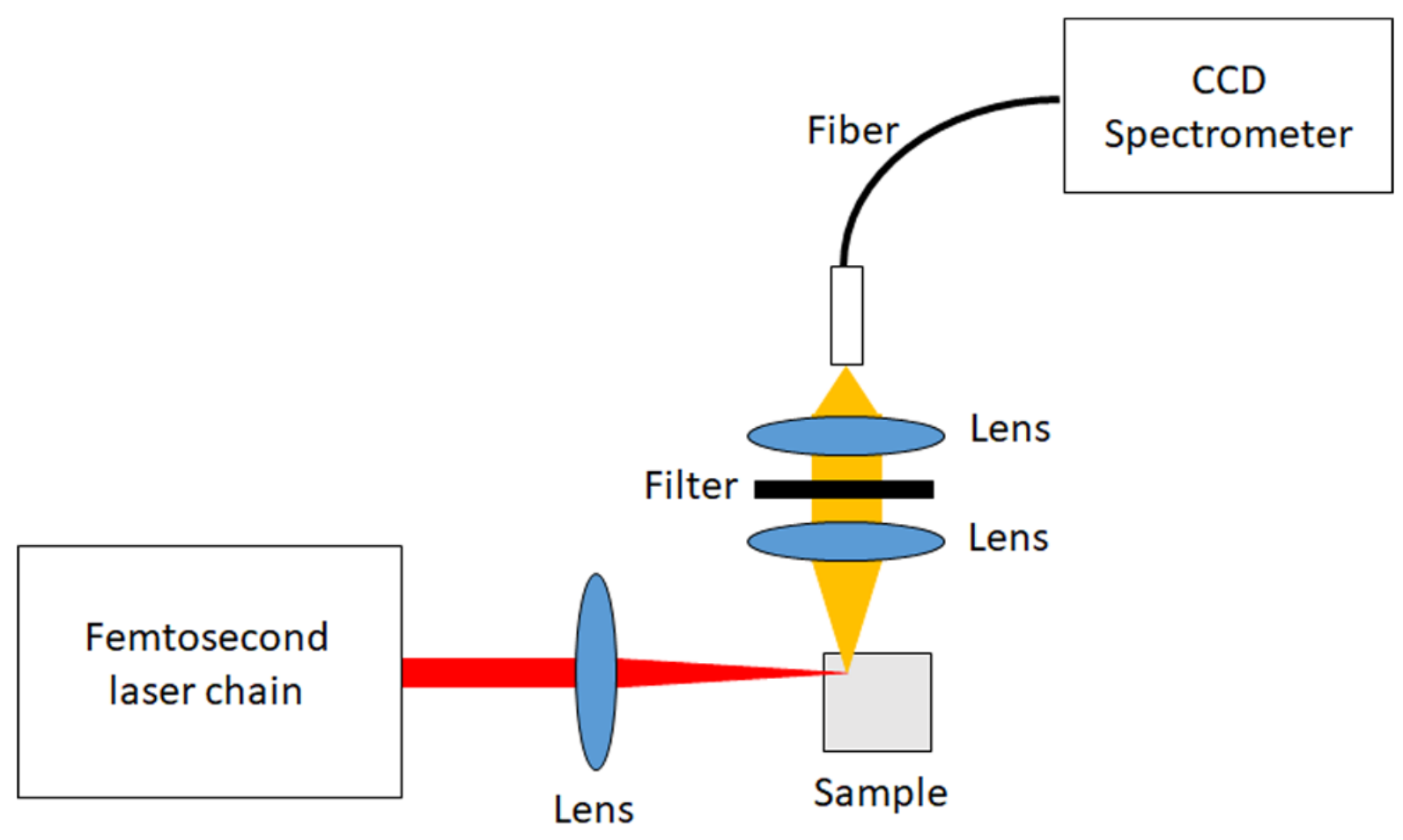

Figure S23. Schematic presentation of the luminescence measurement set-up used for $1 \mathrm{P}$ and $2 \mathrm{P}$ emission measurements.
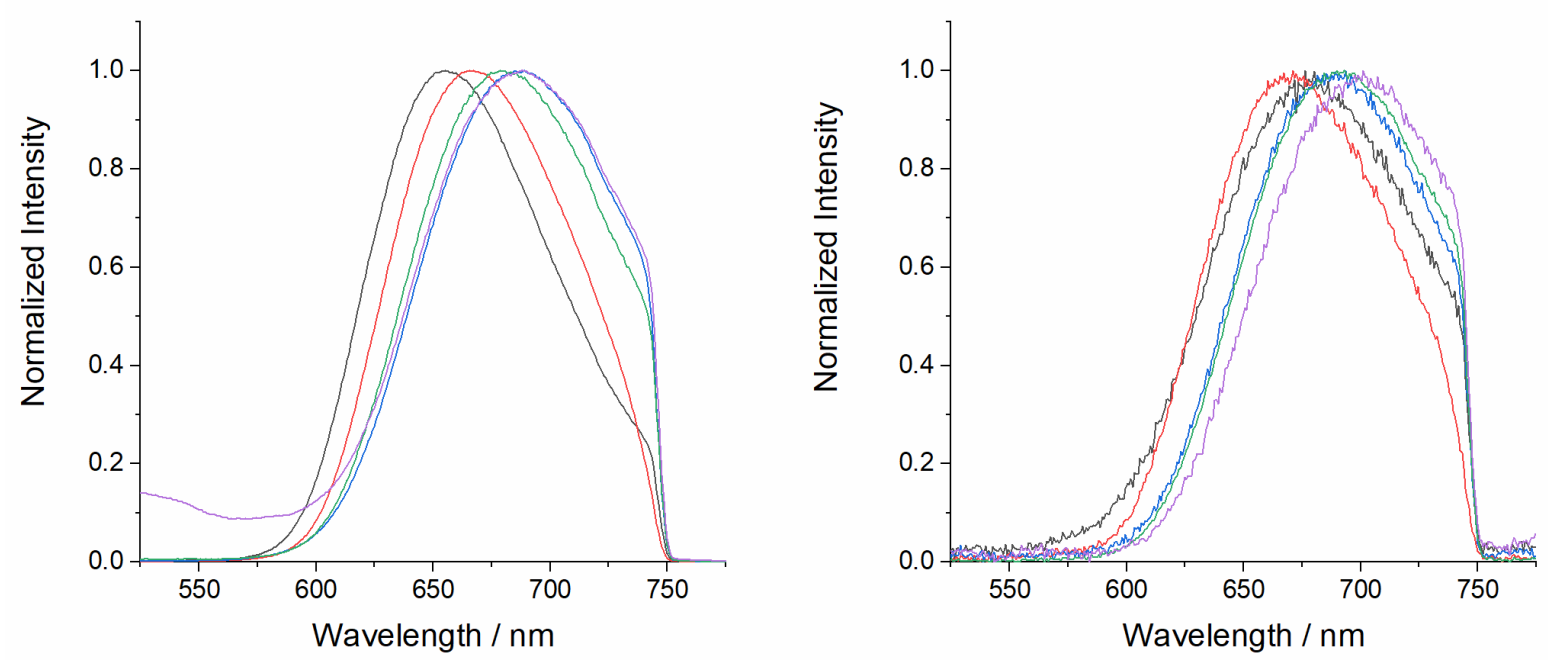

Figure S24. Normalized emission spectra ((left: $\lambda_{\text {exc }}=405 \mathrm{~nm}$, right: $\left.\lambda_{\mathrm{exc}}=810 \mathrm{~nm}\right)$ for $\mathrm{Cs}_{2} \mathrm{Mo}_{6} \mathrm{I}_{8}\left(\mathrm{OCOC}_{2} \mathrm{~F}_{5}\right)_{6}^{\mathrm{a}}$ in powder (black), in deaerated acetone (red), PDMS1 (blue), PDMS5 (green) and PDMS10 (purple) 

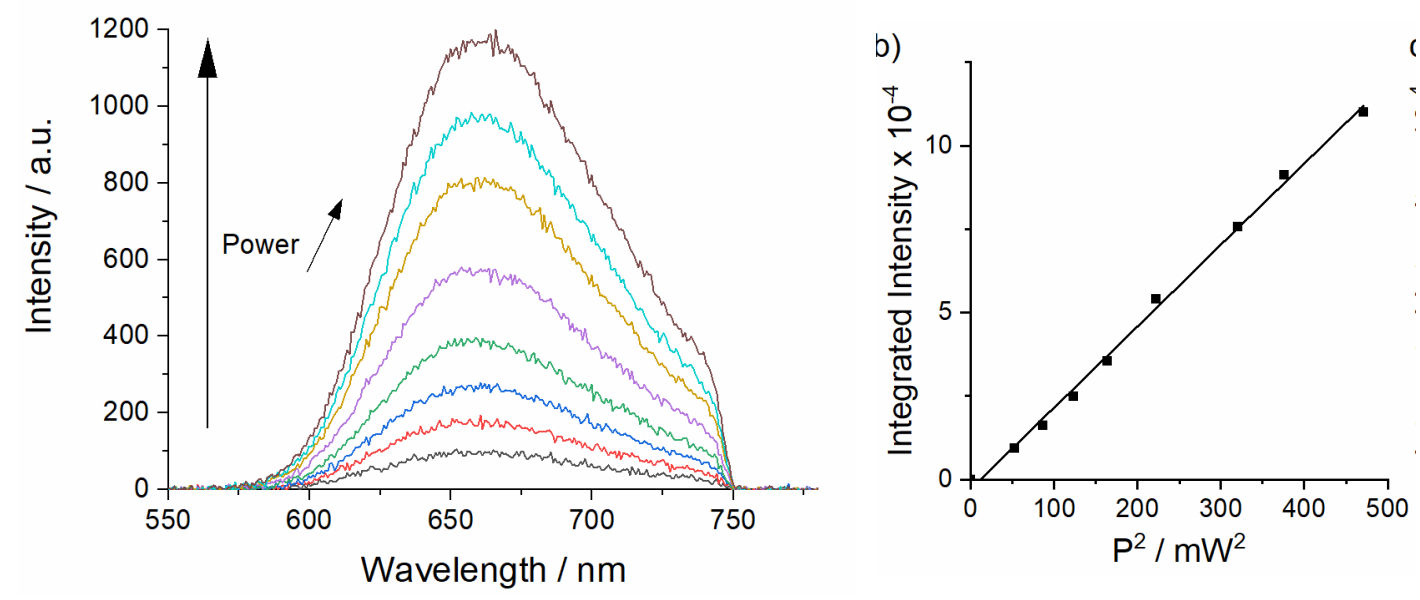

Figure S25. TPA induced emission spectra of $\mathrm{Cs}_{2} \mathrm{Mo}_{6} \mathrm{I}_{8}\left(\mathrm{OCOC}_{2} \mathrm{~F}_{5}\right)_{6}$ in the solid state for $\lambda_{\text {exc }}$ $=810 \mathrm{~nm}$ and various excitation power (left); quadratic dependency of 2PA induced emission intensity with excitation power (right, $\lambda_{\text {exc }}=810 \mathrm{~nm}$ ).

1. Amela-Cortes, M.; Molard, Y.; Paofai, S.; Desert, A.; Duvail, J.-L.; Naumov, N. G.; Cordier, S., Versatility of the ionic assembling method to design highly luminescent PMMA nanocomposites containing [M6Qi8La6]n- octahedral nano-building blocks. Dalton Trans. 2016, 45 (1), 237-245. 